\section{Divisão territorial do trabalho, rede urbana e transporte rodoviário interestadual de passageiros no Brasil}

\section{Bruno Candido dos Santos}

Departamento de Geografia, Faculdade de Filosofia, Letras e Ciências Humanas, Universidade de São Paulo, Brasil.

Recibido: 3 de abril de 2018. Aceptado: 20 de julio de 2018.

\begin{abstract}
Resumo
O transporte rodoviário interestadual de passageiros é uma atividade econômica de central importância para estruturar a circulação de pessoas pelo território brasileiro. Sua origem como serviço organizado remonta à primeira metade do século $\mathrm{XX}$, momento na história brasileira em que se configuram as primeiras rodovias e empresas de transporte de passageiros. Desde então, esta circulação elucidou facetas da divisão territorial do trabalho no país - as áreas mais dinâmicas da economia são dotadas de uma circulação intensa de pessoas, o que evidencia que tal atividade econômica privilegia determinados centros da rede urbana nacional. Atualmente, o transporte rodoviário interestadual de passageiros no Brasil conta com um arcabouço normativo próprio que define a prestação dos serviços - a Agência Nacional dos Transportes Terrestres (ANTT) fiscaliza a atividade, e a operação é de responsabilidade das empresas privadas de transporte. Sendo assim, este artigo debaterá o transporte rodoviário interestadual de passageiros no Brasil: primeiramente será efetuada uma abordagem teórica acerca desta atividade econômica; posteriormente serão elencados aspectos normativos desse serviço e, finalmente, serão debatidos os aspectos operacionais dessas ligações, como número de linhas, quantidade de passageiros transportados, serviços disponíveis, empresas operantes, entre outros aspectos.
\end{abstract}

\section{Territorial division of labor, urban network and interstate road transport of passengers in Brazil.}

\begin{abstract}
The interstate road transport of passengers is an economic activity of central importance for structuring the circulation of people throughout Brazilian territory. Its origin as an organized service dates back to the first half of the twentieth century, a moment in Brazilian history in which the first highways and passenger transport companies are configured. Since then, this circulation has elucidated facets of the territorial division
\end{abstract}

\section{Palavras-chave}

Transporte rodoviário interestadual Circulação de passageiros Divisão territorial do trabalho Rede urbana Serviço público

\section{Keywords}

Interstate road transport Passengers circulation Territorial division of labor Urban network Public service 
of labor in the country - the most dynamic areas of the economy are endowed with an intense movement of people, which shows that such economic activity privileges determined centers of the national urban network. At present, interstate road transport of passengers in Brazil has its own normative framework that defines the provision of services - the Agência Nacional dos Transportes Terrestres (ANTT) monitoring the activity, while the operation is the responsibility of private transport companies. Therefore, this paper will discuss the interstate road transport of passengers in Brazil: first will be performed a theoretical approach about this economic activity, later be scattered regulatory aspects of that service and, finally, will discuss the operational aspects of these links, such as the number of lines, number of passengers transported, available services, operating companies, among other aspects.

\section{Introdução}

O transporte rodoviário de passageiros é uma atividade econômica que expressa a divisão territorial do trabalho, pois conecta áreas distintas e elucida em certa medida como se configura o funcionamento da economia de um país. São deslocamentos que variam em distância, intensidade, frequência, demanda, tempo e pontos abarcados.

Trata-se de uma atividade que é, por excelência, circulação de pessoas inscrita no território, pois engendra deslocamentos que elucidam uma variedade de interações espaciais - estas formam um amplo conjunto de deslocamentos de capital, informação, mercadorias e pessoas pelo espaço geográfico, variando em intensidade, frequência, distância e direção, com distintas velocidades e meios (Corrêa, 2006b).

Sendo assim, o transporte rodoviário de passageiros contém e é contido por diversas interações espaciais, pois possui características normativas (leis; resoluções) e operacionais (frequência; cidades atendidas) próprias, além de ser uma atividade que envolve um conjunto de fixos e fluxos (rodoviárias; linhas; veículos) que configura uma dinâmica particular ao serviço prestado (Santos, 2015, 2018). A análise de todos esses elementos é de extrema importância para que possamos compreender a dinâmica desta atividade no território.

No Brasil, o transporte coletivo rodoviário interestadual de passageiros (responsável por conectar dois ou mais lugares em diferentes unidades da federação) possui função central para os deslocamentos de pessoas pelo território nacional, pois estrutura importante conjunto de fluxos distribuídos por todos os estados brasileiros. Esta atividade econômica é parte da divisão territorial do trabalho, integra regiões variadas dentro de uma rede urbana nacional, perpassa por caminhos distintos na rede rodoviária e interliga centralidades diversas formando um conjunto particular de interações espaciais.

Os fluxos interestaduais são regulados pela Agência Nacional de Transportes Terrestres (ANTT), autarquia responsável pela fiscalização das linhas e das empresas de transporte operantes no sistema. Essas empresas operam o serviço rodoviário desde a primeira metade do século vinte - a primeira empresa estabelecida no setor é a Auto Viação Catarinense, de Blumenau/SC, em 1928. Atualmente o transporte rodoviário interestadual e internacional de passageiros no Brasil é responsável por movimentar anualmente mais de 92 milhões de passageiros, sendo quase $50 \%$ advindos do serviço rodoviário de longa distância (Brasil, 2017).

Segundo Santos e Silveira (2012:179), "quando a presença do poder público no sistema de transportes é insuficiente, os fixos e fluxos passam a pertencer ao domínio mercantil tanto na sua quantidade quanto na sua frequência”. Neste caso, toda a operação do

\section{Palabras clave}

Transporte por carretera interestatal Circulación de pasajeros División territorial del trabajo Red urbana Servicio público 
transporte rodoviário de passageiros coube às empresas privadas, e as estruturas de regulação se modificaram ao longo dessas últimas décadas - a Agência Nacional de Transportes Terrestres foi criada em 2001, ao passo que, até esse ano, as linhas eram fiscalizadas pelo antigo Departamento Nacional de Estradas de Rodagem (DNER).

Este artigo $^{1}$ abordará o transporte rodoviário interestadual de passageiros a partir dos aspectos teóricos, normativos, regulatórios, históricos e operacionais, de modo que seja feito um panorama acerca da atividade no território brasileiro. Serão ressaltadas as informações e análises acerca do serviço de longa distância, que contém a grande parte das linhas interestaduais que possuem mais de 75 quilômetros de extensão, já que aquelas com distância inferior são operadas pelo serviço semiurbano.

A discussão se inicia com a apresentação de categorias e conceitos geográficos que subsidiam as reflexões acerca do transporte rodoviário de passageiros, perpassa pelo debate atinente à regulação da atividade no território brasileiro enfatizando a hibridez do processo, aborda a origem e evolução das empresas de ônibus ao longo do século passado para finalizar com os aspectos operacionais do transporte interestadual, em que se faz uma análise de dados de demanda de passageiros (disponibilizados publicamente pela Agência Nacional de Transportes Terrestres - ANTT) ${ }^{2}$ e ponderações acerca do cenário atual das empresas quanto à renovação de frotas e linhas operadas.

\section{O transporte coletivo rodoviário interestadual de passageiros no Brasil: elementos teóricos para o debate}

Para que seja feito um debate consistente e coeso acerca da circulação de passageiros pelo território nacional se faz necessária a elaboração de um arcabouço teórico que estruture a discussão de forma a elucidar os caminhos possíveis para a abordagem do tema. Este conjunto de categorias e conceitos permite que as dinâmicas do transporte rodoviário de passageiros sejam demonstradas com maior precisão, ou seja, o modo como se dá funcionamento dessa atividade econômica no território.

O transporte rodoviário de passageiros está inscrito no espaço geográfico, que pode ser entendido como "a soma indissociável entre sistemas de objetos e sistemas de ações” (Santos, 2013:87). Esse possui sistemas de objetos compostos pelo conjunto de infraestruturas (rodovias, pontos de parada, postos de fiscalização); empresas transportadoras que possuem equipamentos e funcionários, entre outros. Os sistemas de ações são formados em grande medida pelo serviço de transporte, como a operação das linhas, a criação e aplicação das normas, entre outros. Segundo Santos (2013:86-87):

Os objetos não são as coisas, dados naturais; eles são fabricados pelo homem para serem a fábrica da ação. Hoje, esses sistemas de objetos tendem, em primeiro lugar, a ser um sistema de objetos concretos, isto é, objetos que se aproximam cada vez mais da natureza e buscam imitar a natureza. [...] As ações, por sua vez, aparecem como ações racionais, movidas por uma racionalidade conforme aos fins ou aos meios, obedientes à razão do instrumento, à razão formalizada, ação deliberada por outros, informada por outros.

Sendo portanto uma criação humana, o transporte rodoviário de passageiros está submetido a uma racionalidade em seu funcionamento, que se dá em virtude dos elementos e atributos necessários para sua ocorrência no espaço geográfico. E neste há particularidades expressas pelas atividades que o compõe, de modo que cada subespaço se configura de forma distinta dentro de uma totalidade.
1. Este texto contém parte das reflexões ensejadas desde o trabalho de graduação individual defendido em dezembro de 2015 intitulado "As articulações entre Londrina e São Paulo: uma análise a partir do transporte coletivo rodoviário interestadual de passageiros" e durante o mestrado em curso que se iniciou em julho de 2016 com o título "Dos rincões sulistas ao Polígono Pioneiro: divisão territorial do trabalho e transporte rodoviário interestadual de passageiros". A preocupação com a temática da circulação de pessoas pelo território nacional se iniciou em 2012 nos primeiros semestres da graduação em Geografia na Universidade de São Paulo, portanto este artigo reúne algumas ideias, elementos teóricos e empíricos acerca de tal atividade econômica no Brasil que estiveram na trajetória da pesquisa acadêmica.

2. A Agência Nacional dos Transportes Terrestres disponibiliza gratuitamente os dados de demanda do transporte coletivo rodoviário interestadual e internacional de passageiros em: <http://www.antt. gov.br/passageiros/Dados_Operacionais>. Acesso em: 20/07/2018. 
Diante de tal prerrogativa, cada área em um território participará de forma distinta dentro de um mesmo processo, o que implica em dizer que no transporte rodoviário de passageiros, cada porção territorial é abarcada de uma forma específica - uma cidade pode ter mais linhas para um estado do que outra, ao passo que um município situado em um grande entroncamento rodoviário pode conter um conjunto de estruturas vinculadas ao transporte de passageiros, como garagens e oficinas.

Estas particularidades e ocorrências de certos objetos e ações no território são em grande medida frutos de uma divisão territorial do trabalho, que é uma categoria central para o entendimento do espaço geográfico e das atividades econômicas nele inscritas. Conforme Santos (2012:129), tal categoria "constitui um motor da vida social e da diferenciação espacial", pois os lugares são hierarquizados e em função disto se redefine a capacidade de ação das firmas, instituições e pessoas. A divisão territorial do trabalho é fruto de uma organização deliberada, o que expressa a importância da organização do espaço pelos agentes que o produzem (Santos, 2012, 2013).

A divisão territorial do trabalho é resultado do funcionamento conjunto e coordenado de vários sistemas de objetos e sistemas de ações, portanto, "quanto mais complexa a divisão do trabalho, maior a diversificação e a complexificação dos objetos e das ações, maior a espessura do subespaço correspondente" (Santos, 2013:94). Isso em grande parte pode ser verificado no transporte rodoviário de passageiros, que em virtude das atividades econômicas, sociais e culturais engendradas em cada localidade atendida, demandará particularidades nos atendimentos realizados. "Quanto mais intensa a divisão do trabalho numa área, tanto mais as cidades são diferentes umas das outras quanto ao seu conteúdo" (Santos e Silveira, 2012:208-209).

A ampliação da divisão territorial do trabalho se deve em grande parte ao desenvolvimento das infraestruturas de transporte. No Brasil, sobretudo nos estados das macrorregiões Sul e Sudeste, "os transportes se difundiram e à criação de grandes autopistas se soma, nas regiões mais desenvolvidas, uma criação tão grande ou maior de estradas vicinais; desse modo, a circulação se torna fácil e o território fluido" (Santos, 2013:141). Tal fenômeno de difusão das infraestruturas de transporte propiciou a especialização dos lugares e a hierarquização entre lugares, expressa na rede urbana.

Com a difusão dos transportes e das comunicações, e conforme avança a expansão capitalista, criam-se as condições para que os lugares se especializem, sem a necessidade de produzir tudo para sua reprodução. Assim, ao passo que a economia local deixa de preponderantemente autárquica, estabelece-se uma crescente divisão territorial do trabalho. Esse processo - progressivo e acelerado com a incorporação de novas técnicas - ocasiona uma intensificação dos intercâmbios, que se dá em espaços cada vez mais amplos (Arroyo, 2006:74).

Os intercâmbios efetuados pelo transporte ocorrem entre diversos pontos de um território, por meio de um conjunto indissociável de sistemas de fluxos (materiais ou imateriais) e de sistemas de engenharia (fixos), o que constitui os sistemas de movimento (Santos, 2014; Contel, 2012). A distribuição dos sistemas de engenharia pelo território brasileiro é historicamente desigual e os avanços ocorridos em certas porções do país se devem em grande medida às necessidades do capital produtivo estrangeiro.

A rarefação relativa dos sistemas de engenharia, característica de antigas divisões territoriais do trabalho, não estimulava a presença de outros capitais, fixos ou especulativos, em certas regiões. Uma divisão territorial do trabalho globalizada exige uma trama densa e complexa de sistemas de engenharia, o que leva à difusão dos capitais fixos e constantes e à circulação veloz dos capitais especulativos. Os sistemas de engenharia que antes eram praticamente subordinados às condições 
locais são, cada vez mais, tributários de relações mais amplas. De um controle pulverizado à escala de comunidades isoladas, passaram a depender de um controle unificado que preside a um jogo complexo, social e economicamente, que, hoje, caracteriza a utilização de infra-estruturas instaladas segundo regras científicas e técnicas estritas" (Santos e Silveira, 2012:102).

O transporte rodoviário é um sistema formado pelos fixos, que são os instrumentos que permitem a operacionalização do serviço: podem estar fixados, como rodovias, terminais rodoviários e pontos de apoio; ou serem móveis, como os veículos que circulam pelas vias. A distribuição desses elementos, no entanto, possui desníveis nítidos quanto à quantidade e qualidade das estruturas: enquanto as rodovias nos centros mais dinâmicos da economia brasileira são em grande parte duplicadas e pedagiadas, as áreas mais afastadas da região Concentrada (Santos e Silveira, 2012) possuem porcentagens relativamente menores de rodovias pavimentadas, o que reflete, em última instância, a divisão territorial do trabalho e o desenvolvimento desigual no Brasil.

Essas disparidades quanto aos investimentos e estruturação dos fixos reflete nos fluxos de passageiros, pois viagens mais rápidas são possíveis em grande medida pela condição otimizada das vias. Sendo assim, a divisão territorial do trabalho "é fruto de uma organização deliberada, não sendo deixada ao sabor das combinações ocasionais, ainda que predeterminadas" (Santos, 1994:95).

Um conjunto de elementos que pode auxiliar no entendimento da divisão do trabalho em suas nuanças é formado pelos fixos e fluxos. Ambos formam o espaço econômico: "os fixos provocam fluxos em função de seus dados técnicos, que são geralmente locacionais, mas também em função dos dados políticos.” (Santos, 2014:86-87).

Os fixos configuram um conjunto de fluxos: deslocamentos efetuados por cargas e passageiros que interligam um conjunto de centros inseridos em uma rede geográfica. "Os fixos são os próprios instrumentos de trabalho e as forças produtivas em geral, incluindo a massa dos homens. [...] Os fluxos são o movimento, a circulação e assim eles nos dão, também, a explicação dos fenômenos da distribuição e do consumo" (Santos, 2014:86). O estudo dos fixos e fluxos é uma ferramenta preciosa para o entendimento de categorias clássicas, como produção, circulação, distribuição e consumo.

Os fixos são conectados em grande medida por redes, como a ferroviária e a rodoviária. Elas também são o local de ocorrência dos fluxos e têm a capacidade de possibilitar a execução de novos projetos, de realizar novas formas e integrar áreas diversas. "A rede aparece como o instrumento que viabiliza exatamente essas duas estratégias: circular e comunicar" (Dias, 2012:147). Quando se analisa a expansão do sistema rodoviário pelos rincões do território nacional, integrando áreas até então pouco povoadas aos centros mais dinâmicos da economia brasileira, nota-se justamente a viabilização das duas estratégias citadas anteriormente.

Segundo Raffestin (1993:156), "uma rede é um sistema de linhas que desenham tramas". Estas redes podem ser traduzidas por infraestruturas inseridas no território que são responsáveis por ligar pontos específicos e precisos, o que expressa uma hierarquia destes (Raffestin, 1993). A rede rodoviária é formada primordialmente por rodovias com especificidades vinculadas à intensidade dos fluxos, o que elucida as diferenciações da fluidez territorial no que concerne ao transporte rodoviário de cargas.

Grande parte das obras de infraestrutura nesta rede ocorrem para otimizar a circulação e distribuição de mercadorias, o que faz com que a utilização destas melhorias pelo serviço rodoviário de passageiros esteja a reboque de todos esses investimentos 
na ampliação da rede. "A construção desses fixos, rodovias e as estações rodoviárias, feitas pelo Estado asseguram a reprodução do empreendimento de capital privado das empresas que vão atuar" (Oliveira Neto e Nogueira, 2017:231).

No Brasil o transporte rodoviário foi num primeiro momento um "facilitador" dos deslocamentos. "As rodovias tornaram-se um dos principais instrumentos para a formação de um mercado nacional unificado e para a circulação exigida pela nova divisão territorial do trabalho que se esboçou nas próximas décadas" (Xavier, 2012:333). Ou seja, eram as estradas e, posteriormente as rodovias construídas a partir da década de 1940, as principais vias responsáveis pela integração nacional - este processo "conduz a sistemas de malhas, de nós e redes que se imprimem no espaço e que constituem, de algum modo, o território" (Raffestin, 1993:150-151).

A rede rodoviária está intimamente ligada com a rede urbana, que é um dos principais tipos de redes consagrados pelos estudos geográficos, definida por Corrêa (2006a:311) como um "conjunto de centros funcionalmente articulados, [...] resultado de complexos e mutáveis processos engendrados por diversos agentes sociais". Segundo Corrêa (2006a), na rede urbana se manifestam a integração nacional e a globalização, por intermédio de suas nuanças e especificidades.

Entendemos que para haver rede urbana três condições mínimas devem ser satisfeitas. Primeiramente tratar-se de uma sociedade vivendo em economia de mercado, com transações comerciais envolvendo bens produzidos localmente e bens produzidos externamente. Isto pressupõe uma mínima divisão territorial do trabalho. Em segundo lugar deve haver pontos fixos no espaço onde, de modo permanente ou temporário, as transações são realizadas. Esses pontos fixos, por outro lado, tendem a apresentar outras atividades que garantem a possibilidade das transações serem realizadas. Em terceiro lugar deve haver um mínimo de interações entre esses pontos fixos, interações que refletem e ratificam uma diferenciação hierárquica e/ou em termos de especialização produtiva entre eles (Corrêa, 1997:94).

A rede urbana possibilita uma compreensão do desenvolvimento urbano e regional, já que é simultaneamente condição para e reflexo da divisão territorial do trabalho. Por oferecer vantagens locacionais diferenciadas, elucidando uma hierarquia urbana e uma especialização funcional, esta rede é reflexo dessa divisão, e, por congregar serviços de transporte, armazenagem, bancos, comércio, educação, saúde, entre outros, a rede urbana é condição para a divisão territorial do trabalho (Corrêa, 2006a; Fresca, 2010).

As redes rodoviária e urbana são geográficas, pois "assumem diversas formas de manifestação, tornando-se ainda progressivamente mais importantes. A divisão territorial do trabalho em escala crescentemente mundializada só é possível a partir de numerosas redes técnicas engendradas no bojo da expansão capitalista" (Corrêa, 1997:108). Elas são contextualizadas historicamente, pois são construções sociais integrantes do processo de organização espacial - isso implica em dizer que as vias, os fluxos e as localizações são elementos centrais da reprodução social (Corrêa, 2006b). Através das redes geográficas se realizam as interações espaciais.

As interações espaciais constituem um amplo e complexo conjunto de deslocamentos de pessoas, mercadorias, capital e informação sobre o espaço geográfico. Podem apresentar maior ou menor intensidade, variar segundo a frequência de ocorrência e, conforme a distância e direção, caracterizar-se por diversos propósitos e se realizar através de diversos meios e velocidades.

As migrações em suas diversas formas (definitivas, sazonais, pendulares etc.), as exportações e importações entre países, a circulação de mercadorias entre fábricas 
e lojas, o deslocamento de consumidores aos centros de compras, a visita a parentes e amigos, a ida ao culto religioso, praia ou cinema, o fluir de informações destinadas ao consumo de massa ou entre unidades de uma mesma empresa são, entre tantos outros, exemplos correntes de interações espaciais em que, de uma forma ou de outra, estamos todos envolvidos (Corrêa, 2006b: 279).

O estudo das interações espaciais é de suma importância para a Geografia dos Transportes, pois subsidia um amplo debate sobre os deslocamentos pelo território elucidando as imbricações entre as redes geográficas urbana e rodoviária, podendo ser aplicado a outras redes no espaço geográfico. Essas interações são em grande parte assimétricas, o que explicita diferenças na densidade de fixos e fluxos em certas porções territoriais. Segundo Santos (1980:98), "os transportes chegaram a transformar a economia de regiões inteiras" - essas transformações refletem e são refletidas pelas variações nas interações espaciais, ou seja, nos intercâmbios entre os lugares.

\section{A regulação híbrida no transporte rodoviário de passageiros}

O debate sobre regulação é caro à Geografia dos Transportes. Alguns autores têm ressaltado a importância da norma para a circulação, enquanto mecanismo de controle, fiscalização e padronização do funcionamento das atividades econômicas de transporte. Segundo Santos (2013:95), "um novo sistema se levanta e ganha um papel reitor nas relações sociais, isto é, o subsistema da regulação, sem o qual já não se podem entender os fenômenos espaciais".

A produção da circulação no período atual demanda a regulamentação das atividades de transporte. Segundo Antas Jr. (2003:77), "a norma é parte constituinte do espaço geográfico - sem ela não seria possível compreendê-lo como instância social”. Isso implica em dizer que, no atual momento da sociedade:

A difusão das infraestruturas, comunicando diferentes regiões com um mesmo centro, difundiu a construção de uma consciência de território uno, ao mesmo tempo em que promoveu a capacidade de regular e gerenciar o uso de toda a extensão espacial pertencente ao Estado-nação a partir de um centro decisório (Antas Jr., 2005:117).

O Estado teve papel central na difusão das infraestruturas e na regulação das atividades de transporte nesses sistemas de engenharia. Todavia esse papel passou a ser dividido entre outros agentes: trata-se, portanto, do fim do monismo jurídico e do início e consolidação do pluralismo jurídico, que segundo Faria (1999: 150) "revela a heterogeneidade do direito estatal e a existência de várias ordens jurídicas num mesmo espaço geopolítico, relacionando-se em complementaridade, confrontação ou desarticulação".

Sendo assim, a regulação deixa de ser exclusivamente estatal, de modo que as corporações e organizações de solidariedade passam a produzir regulação, o que configura no atual período a regulação híbrida, Latour (1994) traz uma perspectiva de entendimento dos híbridos, que consideram a indissociabilidade entre sujeito e objeto, conforme Santos (2013) apontara para os sistemas de objetos e sistemas de ações.

Nós mesmos somos híbridos, instalados precariamente no interior das instituições científicas, meio engenheiros, meio filósofos, um terço instruídos sem que o desejássemos; optamos por descrever as tramas onde quer que estas nos levem. Nosso meio de transporte é a noção de tradução ou de rede. Mais flexível que a noção de sistema, mais histórica que a de estrutura, mais empírica que a de complexidade, a rede é o fio de Ariadne destas histórias confusas (Latour, 1994:9). 
Latour alerta para a importância da noção de rede: esta põe em contato os fatos, o poder e o discurso, escancarando a hibridez de tais elementos. Ou seja, tal noção é essencial para a compreensão dos elementos supracitados de forma conjunta. Isto pode ser notado no que tange aos apontamentos do tópico anterior: discurso, poder, objetos, ações e normas estão integrados entre si e de forma conjunta participam das dinâmicas regulatórias. Portanto, pensar a regulação híbrida pode auxiliar na apreensão da multiplicidade de elementos e eventos na atualidade: uma perspectiva dualista que entende Estado e corporações de forma segmentada e distinta não contempla a diversidade de interpretações e entendimentos do atual cenário regulatório em qualquer ponto do planeta.

O Estado deixou de ser o único detentor do poder e o único produtor de regulação. Isso não implica em dizer que este perdeu centralidade, pois ainda dirige as ações através das regras e dos direitos, sendo central para a lei (Hirst e Thompson, 1998). Arroyo (2000) aponta que o território normatizado não é resultado exclusivo da regulação do Estado. "As grandes empresas passam a governar o território e esse fato, cada vez mais, assimila território e mercado" (Arroyo, 2000: 118). O Estado em diversos casos regula e normatiza o território para as corporações.

Nas condições atuais, o que estamos assistindo é a política feita pelas empresas, sobretudo pelas grandes empresas. Quando uma grande empresa se instala, por exemplo, numa cidade média, num Estado como Goiás - e se estivesse em Goiás, eu diria Minas - o que acontece? A grande empresa se instala e chega com suas normas. E todas elas são extremamente rígidas. Essas normas rígidas da empresa são duplicadas porque as técnicas também são normas (Santos, 1997:18).

Mercado e território são cada vez mais sinônimos, e, se as empresas brigam pelo mercado, brigam pelo território. O Estado também está nessa disputa, e as corporações mudam o território com sua ação (Santos, 1997). "O Estado, em certos casos, tenta tomar óbvia essa evolução. Às vezes, consegue fazê-lo, e outras vezes, não” (Santos, 1997:22). Sassen (2010) atenta para o fato de que os interesses privados, tanto nacionais quanto estrangeiros, possuem certo peso no trabalho do Estado e contribuem para configurar uma nova forma de autoridade estatal, "um híbrido que não é totalmente privado e nem totalmente público" (Sassen, 2010:65). Ou seja, nota-se novamente a hibridez presente na produção da regulação.

Sassen (2010) destaca a subordinação das funções públicas de criação de normas aos padrões técnicos que viabilizam uma globalização corporativa. Tal subordinação ilustra a emergência de uma agenda essencialmente privada dentro de uma autoridade pública legítima. "A articulação dessa agenda privada dentro do Estado não depende unicamente da representação formal de interesses privados" (Sassen, 2010:65). Segundo Santos (2012:230), "as normas das empresas são, hoje, uma das locomotivas do seu desempenho e de sua rentabilidade". E tais normas conhecidas como "internas" também abarcam o entorno da companhia, pois seus conjuntos de ações afetam em certa medida o universo geográfico e social em que tal corporação está inserida (Santos, 2012).

Sob a perspectiva de um Estado neoliberal, é a economia que pauta e define a agenda e as decisões jurídicas e políticas (Faria, 1999), ou seja, o âmbito econômico é em grande parte responsável por ditar a regulação produzida no âmbito estatal. Segundo Faria (1999:154), "o direito positivo do Estado-nação já não dispõe mais de condições para se organizar quase exclusivamente sob a forma de atos unilaterais, transmitindo de modo 'imperativo' as diretrizes e os comandos do legislador". O autor ainda destaca que, no contexto de economia globalizada, o 'direito da produção' exerce a centralidade da produção e da transformação do direito positivo, especialmente no âmbito direito fiscal, econômico e trabalhista (Faria, 1999). 
Portanto a regulação híbrida está situada em um contexto de pluralismo jurídico, em que outros agentes, além do Estado-nação, produzem regulação. Segundo Faria (1999:150), o pluralismo jurídico "revela a heterogeneidade do direito estatal e a existência de várias ordens jurídicas num mesmo espaço geopolítico, relacionando-se em complementaridade, confrontação ou desarticulação".

O transporte rodoviário interestadual de passageiros, assim como outros segmentos produtivos, possui uma regulação híbrida, pois não é apenas o Estado o único ente regulador. As empresas do segmento produzem regulação, por intermédio de suas normas operacionais internas que refletem no comportamento de seus funcionários e no funcionamento das próprias companhias e do serviço prestado. E é justamente tal produção que gera os embates entre as operadoras de transporte e a autarquia federal reguladora: estes conflitos se dão em diversas situações, como cumprimento de horários, embarques, oferecimento dos serviços, políticas tarifárias, entre outros exemplos.

Os transportes de passageiros possuem três características que permitem designar como um "serviço público": 1) possui um substrato material onde sua utilidade se dá por toda sociedade de forma contínua; 2) possui um trato social estando diretamente vinculado ao regime de direito público; e 3) o elemento subjetivo onde o Estado é aquele que ocasiona e normatiza a prestação do serviço, ou seja, as empresas participarão da atividade de transporte mediante a delegação e regulamentação do Estado (Oliveira Neto e Nogueira, 2017:232).

Segundo Santos (2012:230) "o espaço, por seu conteúdo técnico, é regulador, mas um regulador regulado, já que as normas administrativas (além das normas internas às empresas) é que, em última análise, determinam os comportamentos". Notase portanto que, mesmo com o esforço empreendido pela Agência Nacional do Transportes Terrestres em fiscalizar o serviço e regular a atividade do setor, as políticas internas das companhias acabam por ditar boa parte das práticas e da operação de transporte.

\section{Normas e regulamentos}

O transporte rodoviário de passageiros passou por mudanças nos primeiros quinze anos do atual século nos âmbitos normativo e operacional. A Agência Nacional de Transportes Terrestres (ANTT) é a autarquia federal competente para a gerência deste serviço de transporte, sendo responsável pela fiscalização e outorga das permissões e autorizações para as linhas. A agência fora criada pela Lei n ${ }^{\circ} 10.233$, de 5 de junho de $2001 .^{3}$

\begin{abstract}
Dispõe sobre a reestruturação dos transportes aquaviário e terrestre, cria o Conselho Nacional de Integração de Políticas de Transporte, a Agência Nacional de Transportes Terrestres, a Agência Nacional de Transportes Aquaviários e o Departamento Nacional de Infra-Estrutura de Transportes, e dá outras providências (Brasil, 2001).
\end{abstract}

As empresas autorizatárias (firmas de transporte de passageiros) são responsáveis pela operação do sistema. ${ }^{4} \mathrm{O}$ transporte rodoviário interestadual de passageiros é um serviço público, que se refere "às facilidades ofertadas aos cidadãos para a concretização dos objetivos comuns, e que são assumidos pelo poder soberano em função de argumentos técnicos, sociais ou econômicos" (Druciaki, 2009:87).

A Agência Nacional de Transportes Terrestres possui três competências de gestão. A concessão se refere às ferrovias, rodovias e transporte ferroviário que seja associado à exploração da infraestrutura. A permissão alude ao transporte coletivo regular de

\section{Disponível em: <http:// www.planalto.gov.br/ccivil_03/ LEIS/LEIS_2001/L10233.htm>.} Acesso em: 09/11/2013.
4. Atualmente, a exploração de serviços de transporte rodoviário interestadual e internacional de passageiros encontra-se sob a égide da Lei $n^{\circ}$ 10.233, de 5 de junho de 2001, da Lei no 8.987, de 13 de fevereiro de 1995, e da Lei n 9.074, de 7 de julho de 1995 , estas regulamentadas pelo Decreto nำ 2.521, de 20 de março de 1998 , e pelas normas aprovadas em Resolução, pela Diretoria Colegiada da ANTT. 
passageiros pelos meios ferroviário e rodoviário que não estão associados à exploração da infraestrutura. Já a autorização compete ao transporte de passageiros por empresas de turismo, sob o regime de fretamento, bem como ao transporte internacional de cargas, ao transporte multimodal e terminais, assim como ao transporte rodoviário interestadual de passageiros (Santos, 2015).

As competências de gestão acima mencionadas diferem quanto ao grau de precariedade, que, conforme Druciaki (2009:89), "no âmbito jurídico em questão refere-se à validade e ao teor do serviço delegado". Tais instrumentos são descentralizadores da prestação de serviços públicos, pois delegam às companhias os serviços que o Estado prestaria (Santos, 2015).

A concessão possui menor precariedade já que se trata de um contrato dotado de maior tempo estipulado do que o de permissão. Há o respeito do prazo por parte do Estado, em que o ente privado é indenizado em caso de rescisão do vínculo contratual. Já a permissão, como outrora mencionado, tem um prazo menor do que o da concessão, podendo ser prorrogável, sem que haja direito à indenização por parte da empresa permissionária, podendo haver rescisão a qualquer momento. A autorização é uma delegação esporádica e, em grande parte dos casos, temporária.

As permissões concedidas às empresas para a operação do transporte rodoviário interestadual expiraram no ano de 2008, após terem sido prorrogadas desde o ano de 2003. Diante deste cenário, a Agência Nacional dos Transportes Terrestres (ANTT) elabora em 2008 a licitação do transporte rodoviário de passageiros - o ProPass Brasil: Projeto da Rede Nacional de Transporte Interestadual e Internacional de Passageiros (Santos, 2015).

No primeiro estudo fora elaborado o Plano de Outorgas, que continha os dados acerca da rede de linhas a ser licitada e os parâmetros operacionais como quantidade de passageiros, viagens e veículos a serem utilizados pelas companhias. Tal estudo resultou em um sistema de transporte que continha 1.967 linhas distribuídas em 18 grupos subdivididos em 60 lotes, com a incorporação de 703 novos atendimentos para municípios em que não existiam ligações regulares. Trinta e quatro cidades integrariam a rede de transporte de passageiros. Foram pesquisadas 179 cidades, com coletas de dados nos terminais rodoviários e fiscais embarcados em viagens rodoviárias. Alguns estudos foram refeitos e características da licitação alteradas (Santos, 2015).

O certame ocorreria no ano de 2014 com 16 grupos subdivididos em 54 lotes com 1.836 linhas. Contudo, a licitação nos moldes previstos não foi realizada. Deve ser destacado, portanto, o posicionamento das empresas e de entidades de classe como a Associação Brasileira das Empresas de Transporte Terrestre de Passageiros (ABRATI), que, no caso do ProPass, se posicionaram de forma contrária ao certame, ${ }^{5}$ com argumentos de ordem econômica e operacional que visaram justificar a não implantação do regime licitatório de concessões.

\section{Como o Estado hoje já não mais consegue promover a coordenação macroeconômica sem o consentimento e a colaboração das 'organizações complexas', a formulação, a implementação e a execução de suas políticas invariavelmente acabam exigindo uma delicada negociação para se superar as eventuais resistências dos conglomerados empresariais (Faria, 1999:176-177).}

O transporte interestadual rodoviário passou a ser operado pelo regime autorizatário, que como visto anteriormente, é, do ponto de vista jurídico, o mais precário. As autorizações para as linhas interestaduais têm um prazo de duração de três anos, e podem ser renovadas desde que a transportadora respeite algumas especificações operacionais durante o período em questão: idade média da frota de 5 anos e idade máxima dos
5. Em reportagem veiculada pela revista Technibus em agosto de 2013 (ano 22, número 109) intitulada "Sai a licitação", Paulo Porto Lima, presidente da Associação Brasileira das Empresas de Transporte Terrestre de Passageiros (ABRATI), defende o setor privado em detrimento do certame elaborado pela autarquia federal. Segundo a matéria: "Outro ponto polêmico é em relação à qualificação técnica. Porto Lima defende que a atividade sempre foi exercida pelo setor privado que acumulou conhecimento técnico ao longo dos anos, e destaca que essas experiências não foram levadas em consideração no momento de estipular as exigências de qualificação para prestação do serviço. 'A exigibilidade da capacidade técnica é muito aberta, não podemos ter noção de quantas empresas não são qualificadas para participar, mas rigorosamente, quem não está atualmente operando no setor, do ponto de vista da Abrati, não estaria qualificado para participar do processo. Porém, da forma como está no edital, todas as empresas que fazem algum tipo de transporte público hoje estariam habilitadas para participar e esse é outro ponto crítico', destaca". Nota-se o posicionamento conservador do presidente da associação de classe que representa o setor, ou seja, reticente à entrada de novas companhias no segmento rodoviário interestadual. 
veículos de dez; frequência mínima dos mercados de uma viagem semanal por sentido; ${ }^{6}$ cadastramento dos motoristas devidamente capacitados conforme as normas do Conselho Nacional de Trânsito (CONTRAN), entre outros (Santos, 2015).

Portanto, o regime autorizatário confere maior flexibilidade ao setor, pois difere das concessões e permissões que perduram por prazos mais longos. As autorizações propiciam, mormente aos grandes conglomerados, a distribuição das linhas entre as companhias (Santos, 2015), o que reforça o poder de tais organizações. Conforme Faria (1999) o poder dos conglomerados econômicos decorre da porção do mercado controlada ou detida por eles. O autor destaca a fragmentação da vida política decorrente da expansão desses grupos e organizações, bem como a modificação do perfil das regulações institucionais e o condicionamento da direção da evolução da sociedade.

Dentro das redes de transporte rodoviário de passageiros existem disputas de mercado que estão em jogo em diversos pontos do território nacional, sendo que esta disputa se concentra nos eixos mais rentáveis para as empresas; enquanto um lugar que possui estradas sem pavimento e com baixa demanda, poucas empresas arriscam seu capital para propiciar a circulação de pessoas (Oliveira Neto e Nogueira, 2017:233).

Segundo Wolkowitsch (1973:164), “a formação de grandes empresas apareceu logo na origem do desenvolvimento do transporte de passageiros” (tradução nossa). ${ }^{7}$ Ou seja, assim como no contexto francês, o transporte rodoviário de passageiros no Brasil experimenta ao longo de sua existência uma concentração de linhas em um número reduzido de firmas e grupos. Ou seja, grandes grupos empresariais do setor, organizados de forma oligopolística, atuam na regulação do território com suas práticas e atributos operacionais.

Almeida (2000) alerta no artigo "Nordeste do Brasil e o monopólio rodoviário de passageiros" para outro fato recorrente, em que as transportadoras pioneiras e locais são adquiridas por companhias maiores e mais robustas no tocante ao transporte interestadual: "os fatos mencionados, encadeiam historicamente o processo implantado na região Nordeste brasileiro, com a retirada dos pioneiros, estes, originados do próprio local" (Almeida, 2000:152).

Tal processo elucida "uma tendência à unificação, não apenas técnica como organizacional" (Santos, 2014:89) das firmas de diversos ramos de atuação, o que pode ser notado no que diz respeito ao transporte rodoviário interestadual de passageiros. Arroyo (2006:81) aponta que "essas empresas e instituições têm uma participação importante nos processos de competição, cooperação e controle do território, isto é, são decisivas no seu uso". Podemos dizer que isto também se aplica no caso das companhias do setor, atuantes na produção da circulação, o que ocasiona reflexos nas interações espaciais e nas redes geográficas, ou seja, no espaço geográfico.

\section{Origem e evolução da atividade no brasil}

A história do transporte rodoviário no Brasil remonta ao início da década de 1920, em que alguns caminhos recebem pavimentação. Em 1922 se pavimenta o Caminho do Mar (ligação entre o Planalto Atlântico Paulista à Baixada Santista), e em 1928 é pavimentada a Rio-Petrópolis (ligação entre a então capital federal brasileira com a região serrana do estado fluminense). A partir de 1927, o presidente Washington Luiz cria mecanismos fiscais para o financiamento de infraestruturas de transporte rodoviário, como o Fundo Especial para Construção e Conservação de Estradas de
6. A frequência mínima dos mercados é de uma viagem semanal por sentido, ou seja, a empresa que deseja operar uma linha deverá realizar uma viagem de ida e uma de volta para que possa manter a autorização expedida pela Agência (Brasil, 2015).

7. Trecho original: "La formation de grandes compagnies est apparue dès l'origine du dèveloppement du transport des voyageurs". 
Rodagem Federais. Em 1937, o presidente Getúlio Vargas cria o Departamento Nacional de Estradas de Rodagem, conferindo autonomia e arrecadação para investimentos em estradas. No ano de 1940 é instituído o Fundo Rodoviário Nacional e em 1944 o Plano Rodoviário Nacional, que tinha como finalidade a elaboração de planos rodoviários estaduais e municipais (Pereira, 2014).

Os marcos normativos e operacionais acima citados indicam a importância da circulação no território brasileiro. Camille Vallaux ressalta o caráter político da circulação: "em uma palavra, a circulação política se mistura sobre a terra com quase todos os fenômenos gerais da circulação econômica, o que não impede à circulação de ter, geralmente, suas trilhas e suas vias particulares" (Vallaux, 1914:272, tradução nossa). ${ }^{8}$ Ou seja, a participação do Estado é central no processo de estruturação e regulação dos transportes no território, pois é o ente responsável pela criação de infraestruturas e normas que em grande medida definirão a circulação no país.

Todavia, o transporte de cargas e passageiros no Brasil se inicia antes da implantação de estruturas normativas e operacionais. As primeiras empresas de transporte rodoviário de passageiros no Brasil surgem ao final da década de 1920 - menciona-se as duas primeiras companhias estabelecidas oficialmente no país: Auto Viação Catarinense (1928) e Viação Garcia (1934), no momento em que as estradas de terra e os caminhos sinuosos e irregulares dificultavam a realização de viagens com grande frequência e densidade (Santos, 2015).

Entretanto, essas e outras empresas, em grande parte formadas por iniciativas próprias de pequenos empresários, mecânicos ou motoristas, foram responsáveis por dinamizar os primeiros deslocamentos de passageiros em áreas com pequena extensão - tal panorama se modifica a partir de investimentos na infraestrutura rodoviária que propiciaram a expansão das linhas em quantidade e extensão. Ao analisar o avanço da cafeicultura pelo norte paranaense, o geógrafo francês Pierre Monbeig ressalta a importância do transporte rodoviário de passageiros para as ligações locais e intrarregionais.

Quando se desembarca do trem, numa dessas capitais surpreende o número e movimento dos caminhões, mais ainda dos ônibus rurais, as altas “jardineiras” sobre as rodas, que afrontam tanto os barrancos dos vales, como as areias dos planaltos. Esse tipo de ônibus assegura três tipos de serviços rodoviários. Primeiramente, há os que penetram na zona rural até os desbravamentos mais afastados; graças às jardineiras, podem sitiantes e colonos facilmente ir e vir à cidade, às vezes, pela manhã, no máximo durante o dia. Um segundo tipo de itinerário assegura as relações entre o grande centro e as vizinhas menores; duplicam eles a estrada de ferro, onde a circulação por este meio não é suficiente. São serviços de arrabalde urbano, que denotam até que ponto cidades como Rio Preto, Londrina e Marília possuem satélites urbanos. Há enfim os ônibus que cobrem os grandes percursos. São combinados certos serviços de modo a permitir a circulação rodoviária, até os patrimônios mais ocidentais: por exemplo, entre Londrina-Apucarana e Maringá, ou entre Marília-Tupã-Lucélia e Gracianópolis. Outros serviços põem a capital regional em contato com outras regiões pioneiras (Monbeig, 1984:364).

A evolução da rede rodoviária propiciou ao transporte rodoviário de passageiros o alargamento de sua área de operação, pois os fluxos de pessoas se intensifica conforme o avanço das infraestruturas e da urbanização no território brasileiro. Segundo Santos (2012:278), “os progressos técnicos e científicos permitem produzir muito mais utilizando uma porção menor do espaço graças aos enormes ganhos de produtividade".

Grandes empresas do setor foram fundadas em diversos estados brasileiros, sobretudo na região Sudeste, como as mineiras Empresa Gontijo de Transportes (1943),
8. Trecho original: "En una palabra, la circulación política se mezcla sobre la tierra con casi todos los fenómenos generales de la circulación económica, lo que no impide a la circulación tener generalmente sus huellas y sus vías particulares". 
e União dos Transportes Interestaduais de Luxo - UTIL (1950); as capixabas Viação Águia Branca (1946) e Viação Itapemirim (1953); as paulistas Empresa de Transportes Andorinha (1948) e Viação Cometa (1948); assim como a fluminense Auto Viação 1001 (1947) (Lima, 2012).

Portanto, o transporte rodoviário interestadual de passageiros estruturou as ligações de longa distância no território brasileiro, demonstrando em certa medida a função social exercida pelo serviço, pois este, em virtude de sua flexibilidade - possibilidade de embarques e desembarques em locais diversos sem qualquer infraestrutura prévia como estações e portos, propiciou uma intensa movimentação de pessoas pelo país ao longo, sobretudo, da segunda metade do século XX.

Isso se verifica pelo aumento da frota de ônibus no Brasil, que "dobra entre 1950 e 1970 para aumentar 6,5 vezes entre este último ano e 1996” (Santos e Silveira, 2012:177). Reafirma-se a importância da circulação rodoviária de pessoas pelo território nacional, e como retrato de tal relevância, diversas empresas registraram aumento da demanda de passageiros na segunda metade do século XX (Figura 1).

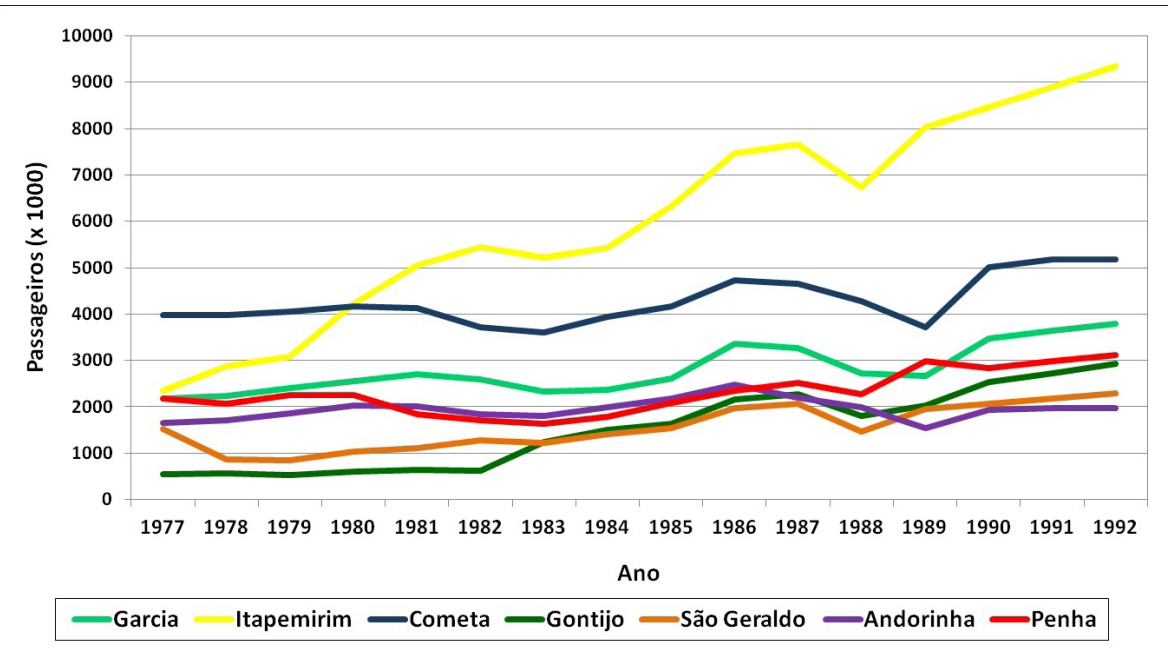

Figura 1. BRASIL: Transporte rodoviário interestadual de passageiros - dados de demanda no período 1977-1992. Fonte: Anuário Estatístico dos Transportes Terrestres (AETT) - ano 1982, 1985, 1988/1989 e 1994. Organização: Santos, B. C., 2015.

Mesmo diante de uma conjuntura recessiva iniciada a partir da segunda metade da década de 1970, a intensificação dos fluxos migratórios internos no Brasil explica o aumento no volume de passageiros transportados pelas 7 maiores empresas do setor na década de 1980 (Figura 1). Vale lembrar que ao longo das últimas décadas as companhias de menor porte foram adquiridas pelas grandes empresas, de modo a acentuar o processo de oligopolização no setor - no ano de 2003 a mineira Gontijo assume o controle da também mineira São Geraldo, formando um dos maiores grupos do país, com mais de 200 linhas rodoviárias interestaduais e internacionais (como a Salvador/BA x Assunção/PAR) e cerca de 2 mil ônibus. ${ }^{9}$ A capixaba Itapemirim fora dona das paranaenses Penha e Kaiowa até o ano de 2007, quando formavam o maior grupo do Brasil. As duas empresas do Paraná foram vendidas ao grupo Áurea, dono da Gol Linhas Aéreas e de um conjunto bastante amplo de companhias de transporte rodoviário e urbano de passageiros. ${ }^{10}$
9. Sobre isso, ver: <https://www. dci.com.br/servicos/gontijoassume-controle-da-s-o-geraldoe-absorve-funcionarios-1.31481>. Acesso em: 20/07/2018.

10. Segundo informações do jornal Folha de São Paulo, o grupo Itapemirim faturou 1 bilhão de reais no ano de 2006 . Sobre isso, ver: <https://www1.folha.uol.com. $\mathrm{br} / \mathrm{fsp} /$ dinheiro/fi2606200721. htm>. Acesso em: 20/07/2018. 


\section{Aspectos operacionais do transporte rodoviário interestadual de passageiros}

Diferentemente do transporte coletivo urbano de passageiros sobre pneus, que conta com maior número de paradas e trajetos mais curtos, o transporte rodoviário possui percursos mais longos em distância e tempo, com tarifas mais custosas e maior variedade de serviços prestados pelas empresas, como poltronas reclináveis, serviço de bordo em algumas linhas, entre outros.

A grande distinção que pode ser feita entre transporte urbano e rodoviário alude à dinâmica dos percursos: uma linha urbana é responsável por interligar múltiplos pontos dentro de um ou mais municípios, com várias paradas em um trecho com poucos quilômetros de extensão, ao passo que um trajeto rodoviário conecta municípios distintos em uma rede de cidades com maior extensão quilométrica.

Outra diferença alude ao tipo de veículo: os ônibus utilizados no transporte urbano, em grande maioria, possuem duas ou mais portas para embarque e desembarque de passageiros, sendo permitido o transporte de pessoas em pé, ao passo que os veículos coletivos rodoviários possuem uma única porta para embarque e desembarque de passageiros, além de espaços abaixo do piso para o carregamento de bagagens.

A Agência Nacional de Transportes Terrestres elabora uma divisão entre dois serviços com base nas especificações de veículos utilizados nos transportes de passageiros. O serviço rodoviário é operado com veículos de uso rodoviário, com apenas uma porta para embarque e desembarque, nos quais é proibido o transporte de passageiros em pé. Já os veículos do serviço semiurbano são coletivos de uso urbano, com duas ou mais portas para embarque e desembarque de passageiros. A cobrança da tarifa é feita no interior dos veículos, que podem transportar passageiros em pé. As linhas semiurbanas possuem extensão máxima permitida de 75 quilômetros.

No transporte interestadual de passageiros as ligações do serviço rodoviário são predominantes. Segundo Santos (2015), de um total de 2.877 linhas, 2.759 (95,9\%) são do serviço de "longa distância" - para a Agência Nacional de Transportes Terrestres (ANTT), autarquia reguladora desta circulação de pessoas, qualquer linha interestadual ou internacional com mais de 75 quilômetros de extensão é considerada de "longa distância", ou seja, do serviço rodoviário. As linhas com extensão menor que 75 quilômetros são pertencentes ao serviço semiurbano, ou seja, linhas de transporte urbano que funcionam como os sistemas municipais e intermunicipais sobre pneus.

Há uma subdivisão interna do serviço rodoviário em classes que variam conforme a reclinação das poltronas (quanto maior em graus a reclinação do assento, maior o preço cobrado por quilômetro com base no coeficiente tarifário), pela presença ou não de sanitário no interior do veículo bem como pela instalação ou não de ar condicionado no ônibus. O semiurbano não possui classes, portanto, o preço por quilômetro varia apenas em função da categoria tarifária de trecho, ${ }^{11}$ que é elaborada a partir do tipo de pavimentação viária ${ }^{12}$ percorrido pela linha.
11. O serviço semiurbano possui um único preço por quilômetro independentemente da pavimentação: R\$̦o,097022. Fonte: Agência Nacional de Transportes Terrestres. Disponível em: $<$ https://appweb.antt.gov.br/SGP/ src.br.gov.antt/apresentacao/ consultas/CoeficienteTarifario. aspx>. Acesso em 28/02/2018.

12. Segundo o Departamento Nacional de Infraestrutura de Transportes (DNIT) as rodovias podem ser classificadas conforme a situação física: "LEITO NATURAL - LEN Rodovia construída em primeira abertura, em terreno natural, sem atendimento às normas, podendo eventualmente receber revestimento primário. Rodovias que não atendem às normas rodoviárias de projeto geométrico, não se enquadrando, portanto em nenhuma das classes de rodovias estabelecidas pelo DNIT. Sua superfície de rolamento se apresenta no próprio terreno natural; IMPLANTADA - IMP: Rodovias construídas de acordo com as normas rodoviárias de projeto geométrico e que se enquadram em determinada classe estabelecida pelo DNIT. Apresentam superfície de rolamento sem pavimentação. Estas rodovias normalmente apresentam sua superfície em revestimento primário e permitem tráfego o ano todo; PAVIMENTADA - PAV: Rodovia com revestimento superior. Rodovias implantadas que apresentam sua superfície com pavimento asfáltico, de concreto cimento ou de alvenaria poliédrica". Fonte: Ministério dos Transportes. Departamento Nacional de Infraestrutura de Transportes (DNIT). Disponível em: <http://www.dnit.gov. $\mathrm{br} /$ download/rodovias/rodoviasfederais/terminologias-rodoviarias/ terminologias-rodoviarias-versao11.1.pdf>. Acesso em 28/o2/2018. 
Quadro 1. BRASIL: Coeficiente tarifário das classes de serviço do transporte rodoviário interestadual de passageiros. Fonte: Agência Nacional de Transportes Terrestres. Disponivel em: <https://appweb.antt. gov.br/SGP/src.br.gov.antt/apresentacao/consultas/CoeficienteTarifario.aspx>. Acesso em 28.fev.2018. Organização: Santos, B. C., 2018.

\begin{tabular}{|l|c|c|}
\hline Classe de serviço & Categoria tarifária de trecho & Valor (R\$) \\
\hline Convencional com sanitário & Pavimentado & 0,168612 \\
\cline { 2 - 3 } & Leito natural & 0,254402 \\
\cline { 2 - 3 } & Implantado & 0,226429 \\
\hline \multirow{3}{*}{ Convencional sem sanitário } & Pavimentado & 0,159001 \\
\cline { 2 - 3 } & Leito natural & 0,239901 \\
\cline { 2 - 3 } & Implantado & 0,213523 \\
\cline { 2 - 3 } & Pavimentado & 0,209079 \\
\cline { 2 - 3 } & Leito natural & 0,315458 \\
\hline \multirow{3}{*}{ Leito com ar } & Implantado & 0,280772 \\
\cline { 2 - 3 } & Pavimentado & 0,382749 \\
\cline { 2 - 3 } & Leito natural & 0,577492 \\
\hline \multirow{3}{*}{ Leito sem ar } & Implantado & 0,513994 \\
\cline { 2 - 3 } & Pavimentado & 0,382749 \\
\cline { 2 - 3 } & Leito natural & 0,577492 \\
\hline Semi-leito & Implantado & 0,513994 \\
\cline { 2 - 3 } & Pavimentado & 0,230998 \\
\cline { 2 - 3 } & Leito natural & 0,348530 \\
\cline { 2 - 3 } & Implantado & 0,310208 \\
\hline
\end{tabular}

As classes de serviços com maior preço por quilômetro são justamente aquelas com poltronas que contém maior reclinação, como a "leito", o que indica que o ônibus possui um número menor de assentos. Portanto, a tarifa maior para veículos com menor quantidade de poltronas funciona em certa medida como uma "compensação" para que a empresa consiga obter as receitas necessárias para a operação da linha.

Nos primeiros anos do atual século, a demanda no transporte rodoviário de passageiros decresceu, ao passo que a do transporte aéreo aumentou.

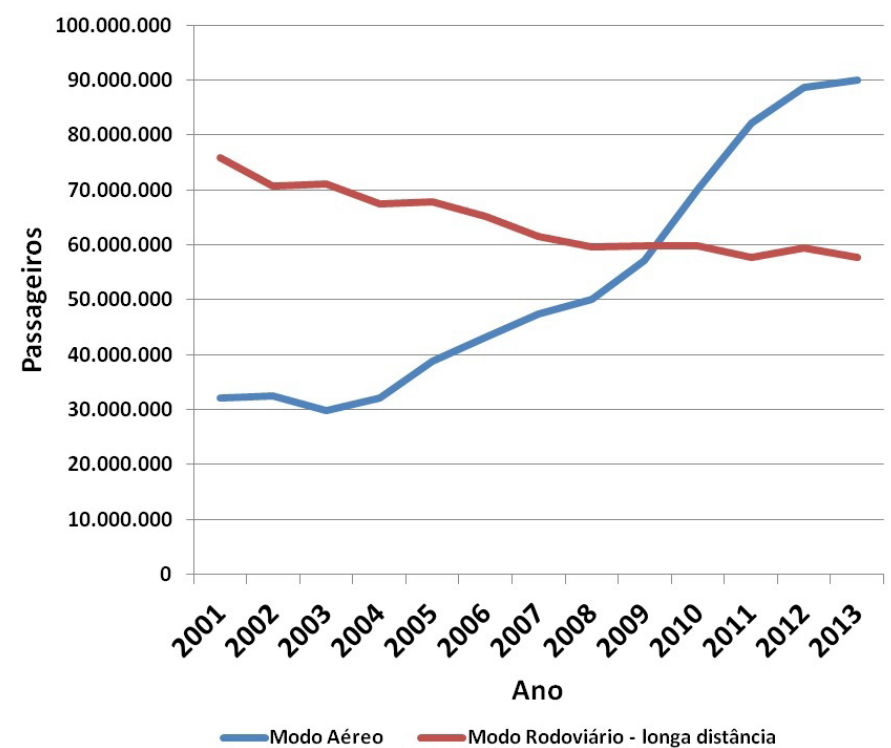

Figura 2. BRASIL: Modo aéreo versus modo rodoviário - dados da demanda no período 2001-2013. Fonte: Anuários Estatísticos da Agência Nacional da Aviação Civil (ANAC) - anos 2009 e 2013 e Agência Nacional dos Transportes Terrestres (ANTT) - período 2001-2008; Sistema de Controle de Dados dos Serviços de Transporte Rodoviário de Passageiros (SISDAP) - período 2009-2013. Organização: Santos, B. C., 2015. 
Nota-se que no período de 2001 a 2013 a quantidade de passageiros no modo aéreo triplicou, ao passo que a do modo rodoviário registrou uma queda de cerca de 20 milhões de usuários. Entretanto esta queda não foi na proporção do aumento no setor aéreo. Isso elucida, de certo modo, a possível entrada de outras classes sociais que anteriormente não utilizavam o transporte rodoviário de longa distância. Ou seja, o transporte rodoviário de passageiros teve, de certa forma, uma alteração de seus usuários em virtude do poder aquisitivo destes. E este mesmo poder foi responsável em grande medida pelo grande crescimento da demanda no modo aéreo.

Essas novas classes usuárias do modo rodoviário foram vislumbradas por agentes econômicos do segmento rodoviário. No ano de 2012 o grupo JCA, formado por empresas como Auto Viação Catarinense Ltda, Auto Viação 1001 Ltda. e Viação Cometa S/A, lançara o programa "Contagiro", que consistiu em um programa de "milhagens" com o lançamento de um cartão de crédito em conjunto com a Caixa Econômica Federal.

Grupo JCA quer ser a 'Multiplus' dos ônibus

As empresas de transporte rodoviário interestadual de passageiros 1001, Cometa e Catarinense, controladas pelo grupo JCA, lançam amanhã um programa de fidelidade inspirado no acúmulo de milhas das companhias aéreas. O objetivo é conquistar novos passageiros e competir com o próprio setor aéreo.

'Queremos ser a Multiplus das pessoas que ainda não têm acesso ao transporte aéreo, como a classe D, e que estão entrando nas viagens de ônibus', diz Marcelo Antunes, membro do conselho de administração do JCA e neto do fundador do grupo, Jelson da Costa Antunes. O executivo refere-se à empresa Multiplus, controlada pela TAM S.A., holding da TAM Linhas Aéreas.

Um dos objetivos, diz Antunes, é unir empresas com o mesmo foco, voltadas para as classes com menor poder aquisitivo, e formar um grupo com vocação para abrir o capital e lançar ações em bolsa, a exemplo da Multiplus, que em fevereiro de 2010 arrecadou R\$ 723 milhões. 'Esse é um sonho nosso'.

A iniciativa do JCA não é inédita no setor de ônibus, mas é a primeira que se assemelha aos programas de milhagem do setor aéreo. Desde 2005, o passageiro da Itapemirim que acumular 10 passagens ganha a 11, , para ser usada nos mesmos trechos percorridos. Para isso, tem de se cadastrar no site. [...]

Batizado de Contagiro, o programa de fidelidade do grupo JCA terá uma primeira fase. Nela, o cliente terá acesso ao acúmulo de pontos (ou "giros") somente se adquirir um cartão de crédito de uma das três empresas (1001, Cometa ou Catarinense), emitido pela Caixa Econômica Federal (CEF), com a bandeira Mastercard [...].

Numa segunda fase, a partir do segundo semestre, qualquer passageiro das empresas do grupo JCA poderá entrar no programa de fidelidade Contagiro. Uma passagem entre o Rio e São Paulo, por exemplo, vale 2.920 'giros'. (KOMATSU, 2015).

Este programa foi encerrado pelo grupo JCA no dia 01 de julho de 2014. Todavia, algumas empresas elaboraram programas semelhantes, como a Brasil Sul Linhas Rodoviárias, que concede pontos aos passageiros cadastrados que podem ser acumulados e trocados por passagens gratuitas. 


\section{Empresas e renovações de frota: ponderações acerca do cenário atual}

$\mathrm{O}$ ano de 2011 registrou a maior quantidade de carrocerias de ônibus produzidas no Brasil. No segmento rodoviário o ano de 2013 foi o mais expressivo (Fabus, 2015). A queda em 2009 do volume produzido alude aos efeitos da crise econômica mundial iniciada em 2008 nos Estados Unidos e em alguns países da União Europeia. Todavia, por conta de medidas governamentais, as vendas cresceram de forma sensível em todos os segmentos de carrocerias (Santos, 2015). A quantidade produzida praticamente dobrou de 2003 (18.794 unidades) para 2011 (35.531 unidades) (Fabus, 2015), o que elucida o dinamismo do setor, já retratado em certa medida pelo crescimento dos desembolsos do BNDES. Vale destacar que o setor de transporte rodoviário de passageiros foi um dos principais consumidores das linhas de crédito do Banco, com destaque para o Finame ${ }^{13}$ (Figura 3).

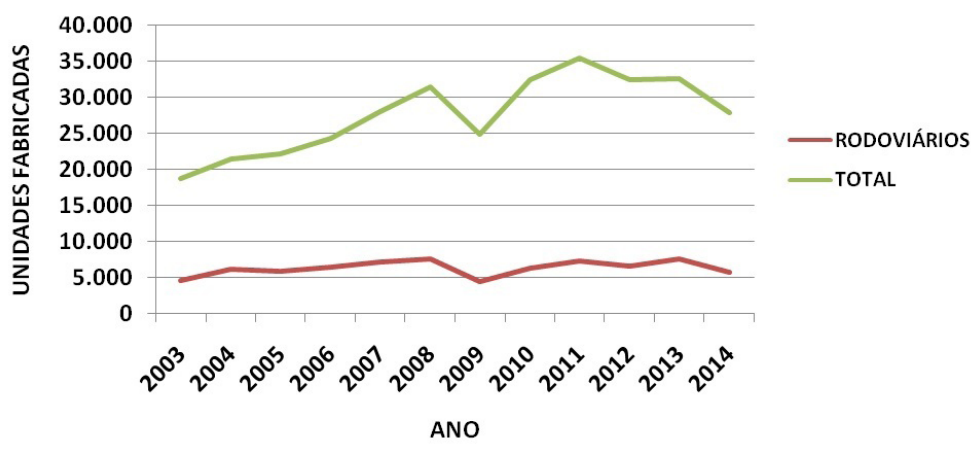

Figura 3. BRASIL: Carrocerias de ônibus produzidas no Brasil - tipo rodoviário e total geral no período 2003-2014. Fonte: FABUS - Associação Nacional dos Fabricantes de Ônibus - Mapas modelos período 2003-2014. Disponível em: <http://www.fabus.com.br/producao.htm>. Acesso em: 06.nov.2015. Organização: Santos, B. C., 2015.

O pico em 2011 (Figura 3) para o total de carrocerias alude em boa parte à entrada em vigor da resolução número 403, de 11 de novembro de 2008, publicada pelo Conselho Nacional do Meio Ambiente (CONAMA), que previa para o dia 1 de janeiro de 2012 a entrada da sétima fase do Programa de Controle da Poluição do Ar por Veículos Automotores (PROCONVE), que corresponde no continente europeu à norma "Euro V"14 (Santos, 2015). Ou seja, além da conjuntura favorável à obtenção de crédito, há de se destacar a busca pela aquisição de veículos com preços menores e sem o custo adicional acarretado pela utilização obrigatória do aditivo ARLA 32, ${ }^{15}$ imprescindível para o bom funcionamento dos motores movidos a diesel produzidos sob a norma "Euro V".

Portanto, a normatização ambiental associada à ampliação das possibilidades de obtenção de crédito e ao novo paradigma normativo no que tange à operação das linhas rodoviárias interestaduais e, no que diz respeito ao transporte urbano, de licitações em diversos municípios brasileiros, acarretou em um cenário de vendas expressivas de carrocerias de ônibus.

\section{Territorialidade da operação: linhas, empresas e passageiros}

As empresas de transporte rodoviário interestadual de passageiros estão presentes em grande parte dos estados da federação, com linhas de extensões variadas e atendimentos distintos. Assim como em outras atividades econômicas, há a concentração de demanda entre poucas companhias: no ano de 2015 foram registradas 240 firmas com 2.744 linhas interestaduais, 37.984 motoristas, 12.479 veículos e 45.850 .799 passageiros transportados. Ao considerar as 20 empresas com maior número de linhas (Quadro 2) é notável a concentração de praticamente metade do total de linhas, passageiros
13. Embora fora do período de análise dos dados, vale mencionar que o Finame financiou cerca de $69 \%$ dos ônibus e caminhões vendidos no primeiro semestre de 2015. Sobre isso, ver: <http:// onibusbrasil.com/blog/2015/o8/19/ finame-financiou-69-dos-onibus-ecaminhoes-vendidos-no-primeirosemestre/>. Acesso em: 15.jan.2017.

14. Sobre isso, ver: <http://onibusbrasil.com/blog/2012/01/18/ montadoras-comecam-2012-semonibus-no-estoque/> e <http:// www.mma.gov.br/port/conama/ legiabre.cfm?codlegi=591> . Acesso em: 06/11/2015. 15. “O ARLA 32 (Agente Redutor Líquido Automotivo), [...] é um produto químico que atua na redução do óxido de nitrogênio (NOx) emitido pelos gases de escape dos veículos" (PETROBRAS, 2017). Disponível em: <http://www.petrobras.com.br/ $\mathrm{pt/produtos-e-servicos/produtos/}$ automotivos/arla-32-flua-petrobras/>. Acesso em: 15/01/2017. 
e motoristas, o que reforça a tese de que o cenário no setor é bastante oligopolizado - vale ressaltar que grande parte das firmas consideradas estão reunidas em grandes grupos empresariais.

Quadro 2. BRASIL: As 20 empresas com maior número de linhas rodoviárias interestaduais - ano 2015. Fonte: Agência Nacional de Transportes Terrestres. Organização: SANTOS, B.C., 2018.

\begin{tabular}{|l|c|c|c|c|c|c|}
\hline Empresa & Município & UF & Linhas & Motoristas & Veículos & Passageiros \\
\hline Gontijo & Belo Horizonte & MG & 216 & 3.384 & 958 & 1.880 .602 \\
\hline Caiçara & $\begin{array}{c}\text { Cachoeiro de } \\
\text { Itapemirim }\end{array}$ & ES & 118 & 635 & 273 & 590.171 \\
\hline Águia Branca & Cariacica & ES & 107 & 919 & 575 & 2.194 .737 \\
\hline Guanabara & Fortaleza & CE & 97 & 1239 & 303 & 1.218 .627 \\
\hline UTIL & Rio de Janeiro & RJ & 97 & 543 & 243 & 1.560 .969 \\
\hline Garcia & Londrina & PR & 86 & 598 & 274 & 1.409 .276 \\
\hline Catarinense & Florianópolis & SC & 84 & 626 & 324 & 2.587 .247 \\
\hline Itapemirim & São Paulo & SP & 81 & 1.865 & 198 & 625 \\
\hline Real Expresso & Brasília & DF & 71 & 304 & 124 & 1.125 .191 \\
\hline Cometa & São Paulo & SP & 60 & 1614 & 512 & 735.962 \\
\hline Santa Cruz & Mogi Mirim & SP & 60 & 419 & 148 & 988.782 \\
\hline Penha & Curitiba & PR & 53 & 213 & 101 & 316.237 \\
\hline Unesul & Porto Alegre & RS & 52 & 651 & 233 & 952.160 \\
\hline Progresso & Jaboatão dos & PE & 46 & 274 & 166 & 607.891 \\
\hline Gransbrasiliana & Goiânia & GO & 45 & 459 & 147 & 410.315 \\
\hline Sampaio & Rio de Janeiro & RJ & 41 & 87 & 43 & 651.276 \\
\hline Riodoce & Caratinga & MG & 40 & 387 & 162 & 862.198 \\
\hline Rotas & Uberlândia & MG & 39 & 380 & 125 & 87.781 \\
\hline EUCATUR & Cascavel & PR & 38 & 717 & 124 & 1.181 .161 \\
\hline 1001 & Niteroi & RJ & 37 & 2.335 & 383 & 1.745 .869 \\
\hline Total & & 1.468 & 17.649 & 5.416 & 21.107 .077 \\
\hline Total Geral & & & 37.984 & 12.479 & 45.850 .799 \\
\hline
\end{tabular}

O Grupo Gontijo é constituído pelas companhias Empresa Gontijo de Transportes Ltda.; Empresa São Cristóvão Ltda., Viação Continental de Transportes Ltda. e Viação Nacional S/A. Do Ceará a São Paulo, da Bahia ao Paraguai, de Rondônia ao Espírito Santo, o grupo opera centenas de linhas, sendo que a grande maioria pertence a Gontijo, que com a anuência concedida pela Agência Nacional dos Transportes Terrestres em 2015, ${ }^{16}$ incorporou em definitivo a Companhia São Geraldo de Viação, que deixou de ter seu cadastro ativo junto à Agência. São linhas que cobrem centralidades em estados das regiões Centro-Oeste, Nordeste, Sudeste e Sul, dinamizando uma grande quantidade de ligações entre a capital paulista e cidades nordestinas. A Viação Nacional possui 22 linhas dispersas por cidades nordestinas, sobretudo em ligações entre cidades do litoral. As empresas Continental e São Cristóvão interligam o Alto Paranaíba com a capital paulista, com a capital federal e com a região do Triângulo Mineiro, respectivamente.

Atuando de Belém/PA a Porto Alegre/RS, o grupo Guanabara é liderado por Jacob Barata, que detém o controle de empresas interestaduais como Expresso Guanabara S.A.; Rápido Federal Viação Ltda.; Real Expresso Ltda.; União dos Transportes Interestaduais de Luxo S.A. (UTIL), Viação Sampaio Ltda. e Brisa Ônibus S.A, estando presente em mais de dez capitais brasileiras. A Guanabara tem sua área de atuação distribuída por boa parte da região Nordeste e engloba a capital paraense, conectando-as à capital federal e à Goiânia/GO. Já a Real Expresso possui diversas linhas na região CentroOeste, tendo Brasília como principal nó de sua operação que se estende para a capital paulista e cidades no Triângulo Mineiro. A UTIL atua no eixo da BR-040 e conecta as

16. Sobre isso, ver: <http://portal. antt.gov.br/index.php/content/ view/41884/Resolucao_n_4845. html>. Acesso em: 20/07/2018. 
centralidades de Brasília (DF), Belo Horizonte/MG, Juiz de Fora/MG e Rio de Janeiro/ RJ, que são as principais cidades para a companhia. Por fim, a Viação Sampaio opera no eixo da Rodovia Presidente Dutra (BR-116), tendo a centralidade do Rio de Janeiro como principal ponto irradiador de suas linhas, ao passo que a Brisa complementa as operações da UTIL partindo do Rio de Janeiro/RJ.

O grupo Águia Branca possui uma atuação relevante no eixo Vitória-Salvador. São 127 linhas distribuídas por duas companhias: Viação Águia Branca S/A e Viação Salutaris e Turismo S/A. A Águia Branca possui rotas oriundas da capital capixaba para cidades da região leste de Minas Gerais, bem como para municípios baianos (inclusive a capital Salvador), fluminenses e para a capital paulista. Já a Salutaris fora incorporada ao final da década de 1990, e suas linhas emanam, em grande medida, da cidade de São Paulo, operando o trecho entre a capital e Vitória da Conquista (BA), contido pela BR-116.

O grupo Itapemirim é formado pelas empresas Viação Itapemirim S/A e Viação Caiçara Ltda. São 195 linhas operadas em grande parte do território nacional, sendo que 192 pertenciam à Itapemirim. Fora por muitos anos a maior companhia do Brasil em número de linhas e frota operante, com ligações entre várias capitais brasileiras, de Porto Alegre a Fortaleza, de Vitória a Porto Velho, passando por cidades nordestinas, sudestinas, do Centro-Oeste, do Norte e do Sul do Brasil. Grande parte dos mercados com maior demanda eram atendidos pela empresa, sobretudo aqueles polarizados por capitais como Belo Horizonte, Brasília, Curitiba, Recife, Rio de Janeiro, Salvador e São Paulo. Contudo, a partir da resolução número 4.662, de 10 de abril de $2015,{ }^{17}$ a companhia passou cerca de 57\% de suas linhas para a Viação Caiçara, além de vender cerca de $40 \%$ de seus ônibus para a mesma, que opera com o nome fantasia "Viação Kaissara”. A Caiçara ficou com grande parte dos mercados mais relevantes, sobretudo aqueles dinamizados pelas capitais do Centro-Sul do Brasil. A Itapemirim ficou com algumas linhas na região Nordeste, além de ligações entre a capital paulista e a fluminense com cidades nordestinas.

A londrinense Viação Garcia Ltda. pertence ao grupo Garcia-Brasil Sul (GBS), que contém mais de uma centena de linhas rodoviárias interestaduais operadas pela própria Garcia e pelas companhias Brasil Sul Linhas Rodoviárias Ltda. e Viação Princesa do Ivaí Ltda. São responsáveis por conectar importantes cidades do norte paranaense como Londrina, Apucarana e Maringá para grande parte das capitais das regiões Sul (Florianópolis/SC e Porto Alegre/RS) e Sudeste (São Paulo/SP e Rio de Janeiro/RJ), além de centros regionais paulistas como Campinas, Bauru, Araçatuba, Presidente Prudente e Ribeirão Preto. Vale ressaltar que o grupo também opera ligações dentro do estado do Paraná que saem do norte paranaense com destino à capital Curitiba e a cidade turística de Foz do Iguaçu.

Com atuação nas regiões Sudeste e Sul, o grupo JCA (a sigla se refere ao nome do fundador da primeira empresa do grupo - Jelson da Costa Antunes) contém as empresas Auto Viação 1001 Ltda.; Auto Viação Catarinense Ltda.; Expresso do Sul S/A e Viação Cometa S/A. De Governador Valadares (MG) à Florianópolis (SC), elas operam nos núcleos mais populosos do país - a fluminense 1001 predomina no estado do Rio de Janeiro, pois além da grande quantidade de linhas intermunicipais ela opera as principais ligações entre centralidades fluminenses (Cabo Frio, Niterói e Rio de Janeiro) e a capital paulista, possuindo 37 interestaduais.

A Catarinense contém uma atuação relevante no eixo São Paulo-Curitiba-Florianópolis, ${ }^{18}$ contendo ligações entre as principais cidades deste conjunto além de 4 linhas internacionais que se destinam à Assunção, capital paraguaia. Em dezembro de 2015, o grupo JCA adquiriu a paranaense Expresso Kaiowa, que continha menos de 10
17. Sobre isso, ver: <http://portal. antt.gov.br/index.php/content/ view/39031/Resolucao_n_4662. html>. Acesso em: 20/07/2018.
18. Sobre isso, ver: <https://diariodotransporte.com.br/2015/12/10/ ministerio-dos-transportes-autoriza-oficialmente-transferenciada-kaiwoa-para-a-catarinense/>. Acesso em: 20/07/2018. 
linhas que operavam a partir de Foz do Iguaçu/PR rumo as capitais paulista, fluminense e mineira. Com tal incorporação, a Catarinense ficou responsável por tais trechos, criando diversas linhas a partir de desdobramentos daquelas pertencentes à Kaiowa, acirrando a concorrência no trecho que contempla o oeste e o norte do Paraná em conjunto com o centro-oeste e o Vale do Paraíba paulista, que são atendidas pelas rodovias BR-369 (rodovia dos Cereais), SP-280 (Rodovia Castello Branco) e BR-116 (Via Dutra). Ou seja, de forma simultânea, a Catarinense se tornou mais presente em diversos eixos no Sudeste e no Sul do Brasil, em trecho bastante concorrido e operado há décadas pela Viação Garcia, hoje pertencente ao grupo Garcia-Brasil Sul, Pluma Conforto e Turismo e mais recentemente pela paranaense Expresso Nordeste. Vale ressaltar que as rotas com destino a Foz do Iguaçu são bem procuradas por compradores de mercadorias em Ciudad del Este, Paraguai, portanto, os ônibus que trafegam nessas linhas possuem boa demanda de passageiros e bagagens.

A Viação Cometa opera as rotas com maior demanda do estado de São Paulo, que são aquelas que se destinam para o litoral sul e para as regiões de Campinas e Sorocaba. A companhia detém 60 linhas, que em grande parte são oriundas da capital paulista. Os trechos entre São Paulo-Curitiba; São Paulo-Belo Horizonte e Rio de Janeiro-Belo Horizonte são operados pela empresa. Por fim, a Expresso do Sul contém 8 linhas presentes nas capitais catarinense, fluminense, paranaense e paulista, o que reforça a predominância do grupo nas ligações entre capitais do Sudeste e do Sul do Brasil, elucidando a forte presença em áreas cuja divisão territorial do trabalho é mais intensa.

A Viação Santa Cruz, oriunda de Mogi Mirim/SP, possui grande parte de suas linhas com origem na capital paulista com destino a municípios na porção sul do estado de Minas Gerais, como Alfenas, Três Corações, Pouso Alegre, Varginha, São Sebastião do Paraíso, entre outras. Embora a área seja relativamente pequena em comparação a outros grupos mais robustos, a quantidade de horários e passageiros transportados é relevante, pois são ligações curtas com demanda anual relativamente constante.

O Grupo Comporte detém o controle da Gol Linhas Aéreas. Trata-se de um dos maiores grupos empresariais do setor de transporte de passageiros do Brasil. São diversas empresas nos segmentos urbano municipal, intermunicipal e metropolitano, bem como no rodoviário intermunicipal e interestadual. São 139 linhas rodoviárias interestaduais operadas pelo grupo, que contém as empresas Expresso Maringá Ltda.; Expresso Itamarati S.A., Expresso União Ltda., Empresa de Ônibus Nossa Senhora da Penha, Empresa de Ônibus Princesa do Norte S.A. e Empresa de Ônibus Pássaro Marron S.A. No tocante ao rodoviário interestadual, são sete empresas.

A Penha é uma empresa relevante no transporte interestadual de passageiros. No grupo Comporte, é a companhia com a maior quantidade de linhas (53), possuindo ligações que dinamizam o eixo Porto Alegre-Curitiba-São Paulo-Rio de Janeiro, contidos pela rodovia BR-116. As capitais fluminense, gaúcha e paulista são suas principais centralidades, de onde emanam boa parte de suas linhas. Suas ligações se dão, em grande medida, no setor Região Sul-São Paulo e Rio de Janeiro, além de outras linhas entre cidades nestas regiões.

A porto-alegrense Unesul de Transportes Ltda. é uma das principais companhias da região Sul do Brasil. Recentemente foi adquirida por uma parceria entre as gaúchas Planalto Transportes Ltda. e Viação Ouro e Prata S.A., configurando uma das operações mais abrangentes nas ligações regionais sulistas. A Unesul opera diversas ligações entre Porto Alegre/RS e outras cidades gaúchas como Erechim, Passo Fundo e Caxias do Sul com cidades do interior dos estados de Santa Catarina, como Chapecó e Joaçaba, e Paraná, como Cascavel, Foz do Iguaçu, Guaíra e Toledo. 
A Auto Viação Progresso é da Região Metropolitana de Recife, sendo uma das maiores empresas nordestinas. Fundada em 1932 (Lima, 2012), atualmente opera em grande parte das capitais do Nordeste, com exceção de Fortaleza/CE, efetuando ligações entre centros regionais no interior nordestino, como Caruaru/PE, Iguatu/CE, Arapiraca/AL, Campina Grande/PB, entre outros.

A goiana Transbrasiliana operava até 2016 um importante conjunto de ligações no eixo contemplado pela rodovia federal Belém-Brasília (BR-010), que conecta as capitais Brasília/DF, Palmas/TO e Belém/PA. Todavia, com dificuldades na operação em virtude de dívidas, a empresa teve suas linhas cassadas pela ANTT, ${ }^{19}$ e o grupo também composto pelas empresas Viação Goiânia Ltda., Viação Araguarina Ltda. e Rápido Marajó Ltda. teve suas operações reduzidas. As ligações restantes estão divididas entre as três últimas companhias, sendo a Marajó a única atuante no eixo da BR-010, contendo algumas ligações que percorrem essa rodovia com origem em Goiânia.

Em abril de 2018 a Transbrasiliana retomou suas operações mediante autorização judicial. ${ }^{20}$ A companhia tem desde então um retorno gradual de suas atividades ao longo do eixo da rodovia Belém-Brasília, em mercados cuja atuação fora predominante até a última década, mas que diante da entrada de novas empresas no setor, como a goiana Expresso Satélite Norte, teve queda na demanda de passageiros.

A mineira RioDoce possui 40 linhas para cidades da porção leste do estado de Minas Gerais. Boa parte delas se destinam à cidade do Rio de Janeiro, enquanto outras se encerram em Vitória/ES, Vitória da Conquista/BA, Juiz de Fora/MG e Governador Valadares/MG, estando concentradas no eixo da BR-116, a rodovia "Rio-Bahia”. Trata-se de uma atuação importante dentro de um trecho concorrido na dinâmica do transporte rodoviário interestadual.

O grupo RodeRotas opera 61 linhas. Sua principal área de atuação está na região do Triângulo Mineiro, especialmente no tocante à cidade de Uberlândia. É composto pelas companhias Rotas de Viação do Triângulo Ltda., Nacional Expresso Ltda., Viação Estrela Ltda. e Expresso Araguari Ltda. Dessas ligações, 38 pertencem à companhia Rotas do Triângulo, que dinamiza as ligações no eixo Brasília-Goiânia-Uberlândia-São Paulo-Santos, contido pela BR-050. As centralidades mais relevantes para a empresa são os municípios goianos de Goiânia e Itumbiara, bem como a cidade mineira de Uberlândia. A Nacional Expresso contém 8 linhas e dinamiza alguns trechos de longa extensão, como Goiânia/GO-Curitiba/PR e Araguari/MG-Foz do Iguaçu/PR. Já a Expresso Araguari contém 10 linhas, sendo 9 oriundas da cidade que dá nome a companhia. Por fim, a Estrela contém três linhas que emanam da capital federal rumo às cidades de Ituiutaba/MG e Paranaíba/MS.

O grupo Eucatur possui quatro empresas: Eucatur - Empresa União Cascavel de Transportes e Turismo Ltda.; Viação Nova Integração Ltda; Transportes Coletivos Serra Azul Ltda. e Solimões Transportes de Passageiros e Cargas Ltda. Vale ressaltar que as duas primeiras (Eucatur e Nova Integração), segundo a Agência Nacional de Transportes, operam mediante autorização judicial, portanto, (sobretudo a Eucatur) possuem um conjunto reduzido de linhas. É nesse contexto que é criada a Solimões, que assume grande parte das linhas da Eucatur, o que não acarretou em nenhuma mudança operacional substantiva.

A Empresa União Cascavel de Transporte e Turismo Ltda., conhecida como EUCATUR, dinamiza ligações entre as regiões Norte, Centro-Oeste e Sul. As centralidades de Cascavel/PR, Cuiabá/MT, Florianópolis/SC, Porto Alegre/RS, Porto Velho/RO e Tubarão/SC são as mais importantes para a empresa que continha 37 linhas até 2015 vale ressaltar, porém, que atualmente a empresa possui apenas 3, pois as demais foram repassadas para a Solimões Transportes Coletivos e Cargas. O eixo Cascavel-Porto
19. Sobre isso, ver: <https://onibusparaibanos.com/2016/05/20/ antt-cassa-servicos-da-transbrasiliana/>. Acesso em: 01/03/2018.

2o. Sobre isso, ver: <http:// www.fortalbus.com/2018/o4/ transbrasiliana-retorna-operacaode.html>. Acesso em: 20/07/2018. 
Velho é o mais relevante para a companhia. Segundo Huertas (2007:130) “a logomarca da empresa, duas cobras entrelaçadas, simboliza a união entre os Estados de Rondônia e Paraná, que protagonizaram um dos maiores fluxos migratórios já registrados na história do Brasil”.

O transporte rodoviário interestadual de passageiros no Brasil é reflexo da divisão territorial do trabalho, pois quando são analisados os dados de demanda por município, unidade federativa ou linhas, algumas porções do território nacional se sobressaem (Figura 4).

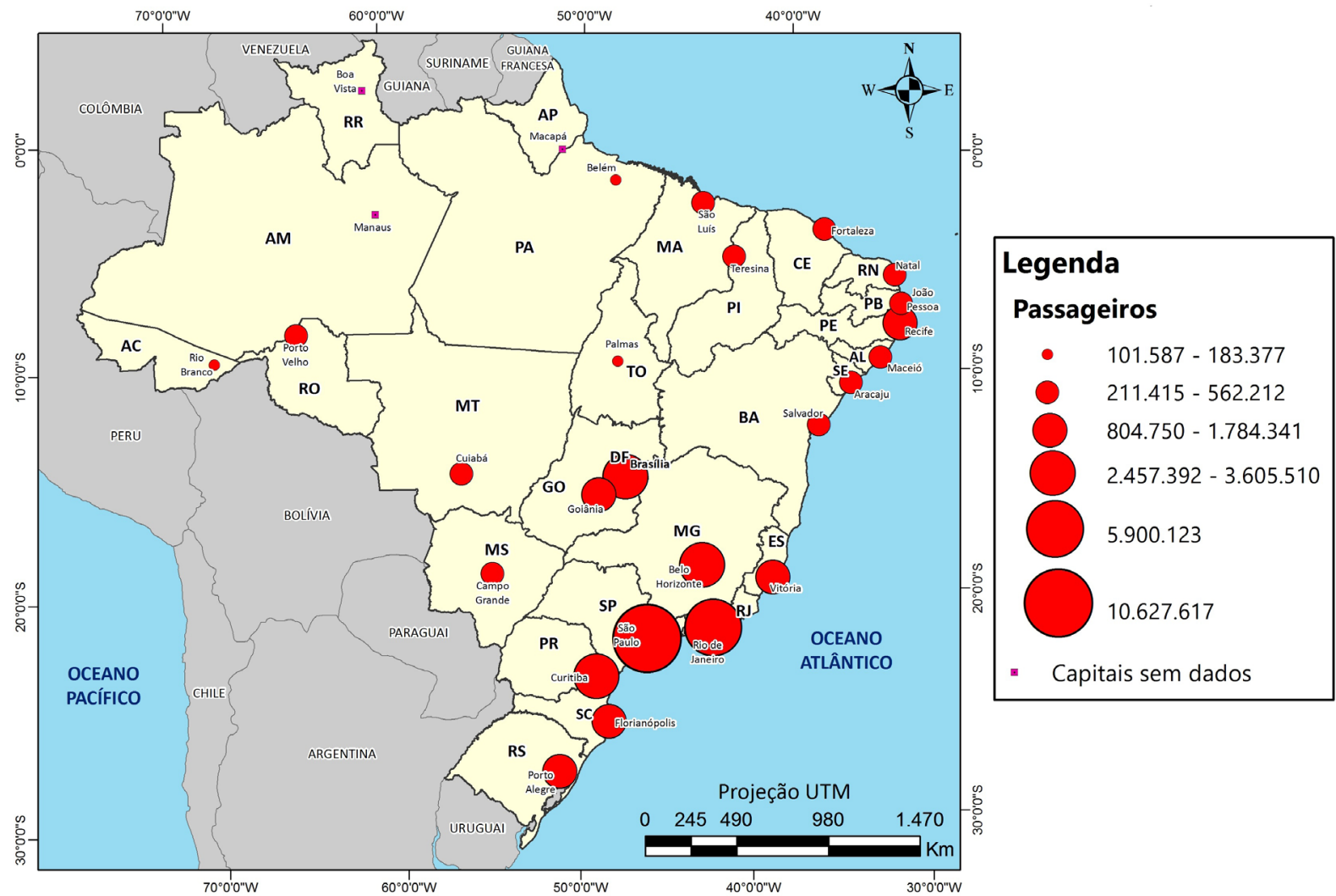

Figura 4. BRASIL: Número de passageiros por capital de estado no serviço rodoviário - ano 2009. Fonte: Anuário Estatístico da Agência Nacional dos Transportes Terrestres (ANTT) - ano 2009 (ano-base: 2008). Base cartográfica: Departamento Nacional de Infraestrutura de Transportes (DNIT); Instituto Brasileiro de Geografia e Estatística (IBGE). Organização e elaboração: Santos, B. C., 2018.

Nota-se a primazia das capitais da região Sudeste, São Paulo/SP, Rio de Janeiro/ RJ e Belo Horizonte/MG, com destaque também para Goiânia/GO, Brasília/DF e Curitiba/PR. Este mapa reflete a rede urbana brasileira, pois os centros mais populosos e economicamente mais dinâmicos possuem os maiores valores para o transporte de passageiros. Ressalta-se que Manaus/AM e Boa Vista/RR não têm dados de demanda para o ano de 2009 - isso ocorre em virtude da rarefeita articulação entre ambas com o restante da rede urbana nacional via sistema de movimento rodoviário, ou seja, a baixa circulação anual de passageiros entre essas duas capitais com as demais áreas do Brasil. Um exemplo para tal cenário é a ausência de uma linha rodoviária que conecte São Paulo/SP com Manaus/AM ou Boa Vista/RR destaca-se o fato da capital paulista ter linhas para todas as capitais de estados do Brasil. Por fim, na base de dados consultada não constam dados para as capitais de estado Boa Vista/RR, Macapá/AP e Manaus/AM. 
Quando se analisa os dados por unidade da federação, a realidade é ligeiramente distinta (Figura 5), pois ao considerar todos os centros atendidos pelo transporte rodoviário interestadual, reforça-se a presença de outras centralidades em cada estado.

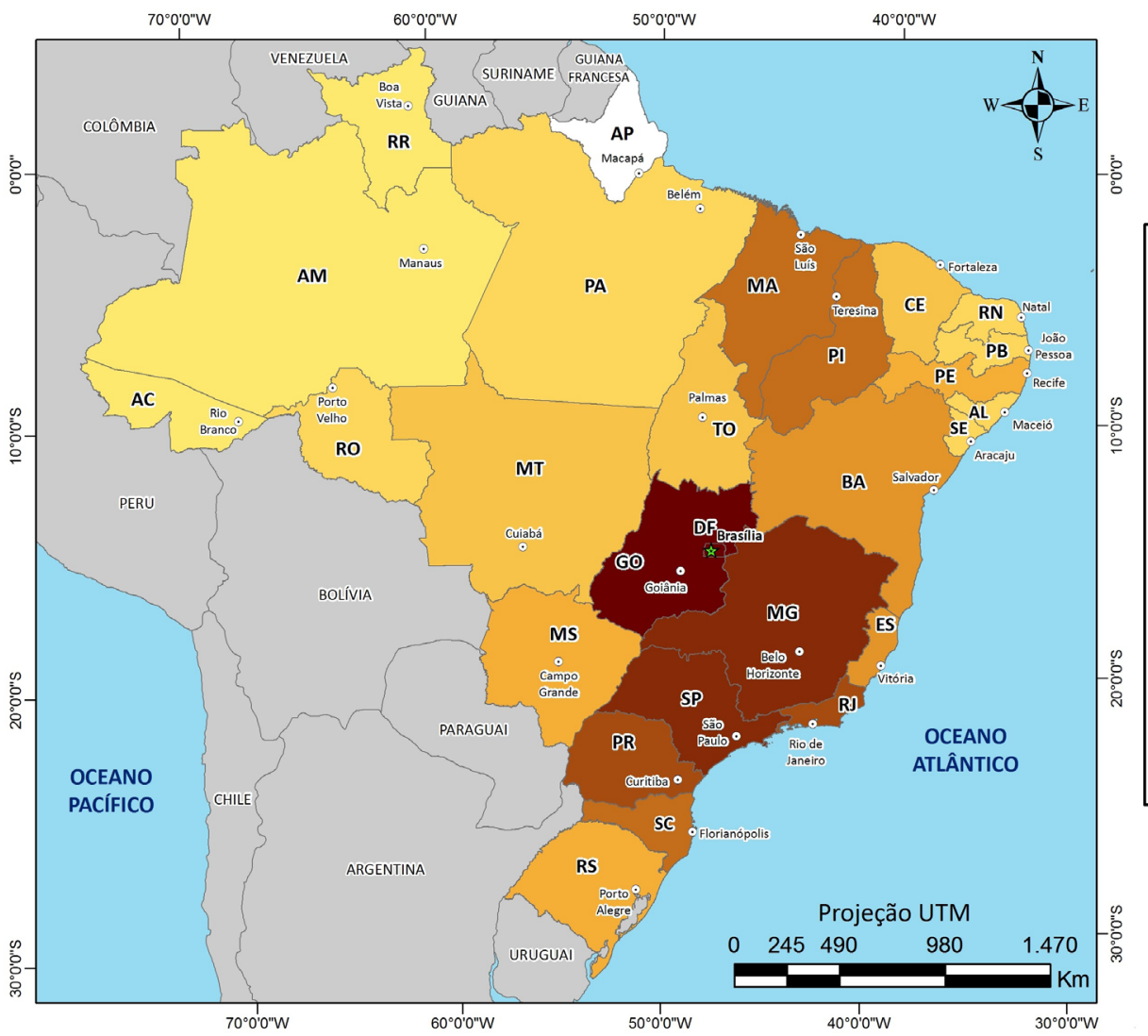

Figura 5. BRASIL: Número de passageiros por Unidade da Federação nos serviços rodoviário e semiurbano no período 2010-2015. Fonte: Anuário Estatístico do Transportes Terrestres (AETT) período 2010-2016. Base cartográfica: Departamento Nacional de Infraestrutura de Transportes (DNIT); Instituto Brasileiro de Geografia e Estatística (IBGE). Organização e elaboração: Santos, B. C., 2018.

O estado do Amapá não possui no período 2010-2015 linhas rodoviárias interestaduais regulamentadas pela Agência. As três unidades federativas com as demandas mais baixas (Roraima, Acre e Amazonas) são justamente aquelas com menor densidade de linhas e de infraestrutura rodoviária. Novamente as áreas mais dinâmicas da economia brasileira e demograficamente mais densas são destacadas, como os estados de São Paulo, Minas Gerais, Rio de Janeiro e Paraná.

O Distrito Federal e o estado de Goiás possuem os maiores valores em decorrência da grande participação do serviço semiurbano. A demanda de passageiros nas linhas oriundas da capital federal com destino às cidades do entorno distrital, como Valparaíso de Goiás/GO, Águas Lindas de Goiás/GO, Planaltina/GO, entre outras, é expressiva em virtude da pendularidade desses centros com Brasília - são linhas que registraram mais de 5 milhões de passageiros ao ano. O mesmo se aplica aos estados do Maranhão e Piauí, já que a ligação entre Teresina/PI e Timon/MA, municípios limítrofes, é operada dentro do semiurbano, que no período considerado para o mapa registrou 39 milhões de passageiros. Ou seja, com a subtração de tais valores referentes a este serviço, a primazia dos estados do Sudeste e do Sul

\begin{tabular}{|l|}
\hline Legenda \\
Demanda \\
$\square$ Sem dados \\
$\square 555.492-1.704 .209$ \\
$\square .907 .572-7.242 .116$ \\
$\square 8.725 .384-10.636 .984$ \\
$16.443 .260-20.794 .617$ \\
$29.870 .720-36.097 .438$ \\
$48.146 .712-51.666 .822$ \\
$71.460 .746-76.901 .704$ \\
$138.775 .164-167.680 .355$ \\
$\square 383.501 .579-398.031 .015$ \\
\hline
\end{tabular}

\section{Legenda}

emanda

doi: 10.34096/rtt.i20.6387 
é novamente reforçada, bem como unidades federativas que ficaram com pouco destaque terão mais evidência.

A análise das ligações rodoviárias de longa distância com maior demanda de passageiros reforça a maior densidade demográfica na região Sudeste e nos centros urbanos ao longo do litoral nordestino e das capitais sulistas, bem como no eixo Goiânia/GO-Brasília/DF. Segundo o Instituto Brasileiro de Geografia e Estatística (IBGE), em estudo realizado no ano de 2016 sobre as ligações rodoviárias e hidroviárias no Brasil:

Goiânia (GO), como capital estadual, embora hierarquicamente inferior na rede urbana, tem sua articulação facilitada pela proximidade com Brasília (DF), especialmente no que diz respeito às atividades geradoras de city-ness, de alto valor agregado. Essas ligações têm no transporte terrestre seu meio preferencial, já que a distância curta não justifica o transporte aéreo, diferentemente do que acontece com o par Rio de Janeiro (RJ)-São Paulo (SP) (IBGE, 2017).

Nota-se que para o trecho entre Rio de Janeiro/RJ e São Paulo/SP, dois dos centros mais ativos da economia brasileira, o transporte aéreo possui certa importância, em virtude da distância de aproximadamente 400 quilômetros entre eles, o que não se aplica entre Goiânia e Brasília, que estão a 230 quilômetros de distância. Essa mesma ideia se reflete nas ligações rodoviárias entre capitais nordestinas como Maceió/AL e Recife/PE, pois a proximidade entre elas propicia ao transporte rodoviário conter a grande parte dos deslocamentos coletivos interestaduais de passageiros (Quadro 3).

Quadro 3. BRASIL: As 15 ligações rodoviárias interestaduais de longa distância com maior demanda período 2010-2015. Fonte: Anuário Estatístico dos Transportes Terrestres (AETT) da Agência Nacional de Transportes Terrestres (ANTT). Organização: SANTOS, B.C., 2018.

\begin{tabular}{|l|c|c|c|}
\hline Ligação & $\begin{array}{c}\text { Passageiros } \\
\mathbf{2 0 1 0 - 2 0 1 5}\end{array}$ & Ligação & $\begin{array}{c}\text { Passageiros } \\
\text { 2010-2015 }\end{array}$ \\
\hline Rio de Janeiro/RJ - São Paulo/SP & 8.654 .531 & Maceió/AL- Recife/PE & 1.150 .172 \\
\hline Braślia/DF - Goiânia/GO & 3.324 .715 & João Pessoa/PB - Recife/PE & 1.138 .483 \\
\hline Curitiba/PR - São Paulo/SP & 3.054 .375 & Rio de Janeiro/RJ - Vitória/ES & 1.122 .612 \\
\hline Juiz de Fora/MG - Rio de Janeiro/RJ & 2.862 .016 & Niterói/RJ - São Paulo/SP & 1.109 .553 \\
\hline Belo Horizonte/MG - São Paulo/SP & 2.708 .656 & Aracaju/SE - Salvador/BA & 1.109 .548 \\
\hline Belo Horizonte/MG - Rio de Janeiro/RJ & 2.396 .811 & Anápolis/GO - Brasília/DF & 1.100 .809 \\
\hline Curitiba/PR - Joinville/SC & 2.016 .386 & Pouso Alegre/MG - São Paulo/SP & 1.099 .756 \\
\hline Curitiba/PR - Florianópolis/SC & 1.465 .391 & TOTAL & 34.313 .814 \\
\hline
\end{tabular}

A quantidade de passageiros no eixo Rio-São Paulo é maior do que as duas ligações subsequentes, entre Brasília e Goiânia e Curitiba e São Paulo. Verifica-se a presença de um número relativamente reduzido de cidades, com a repetição delas em várias ligações (Figura 6). 


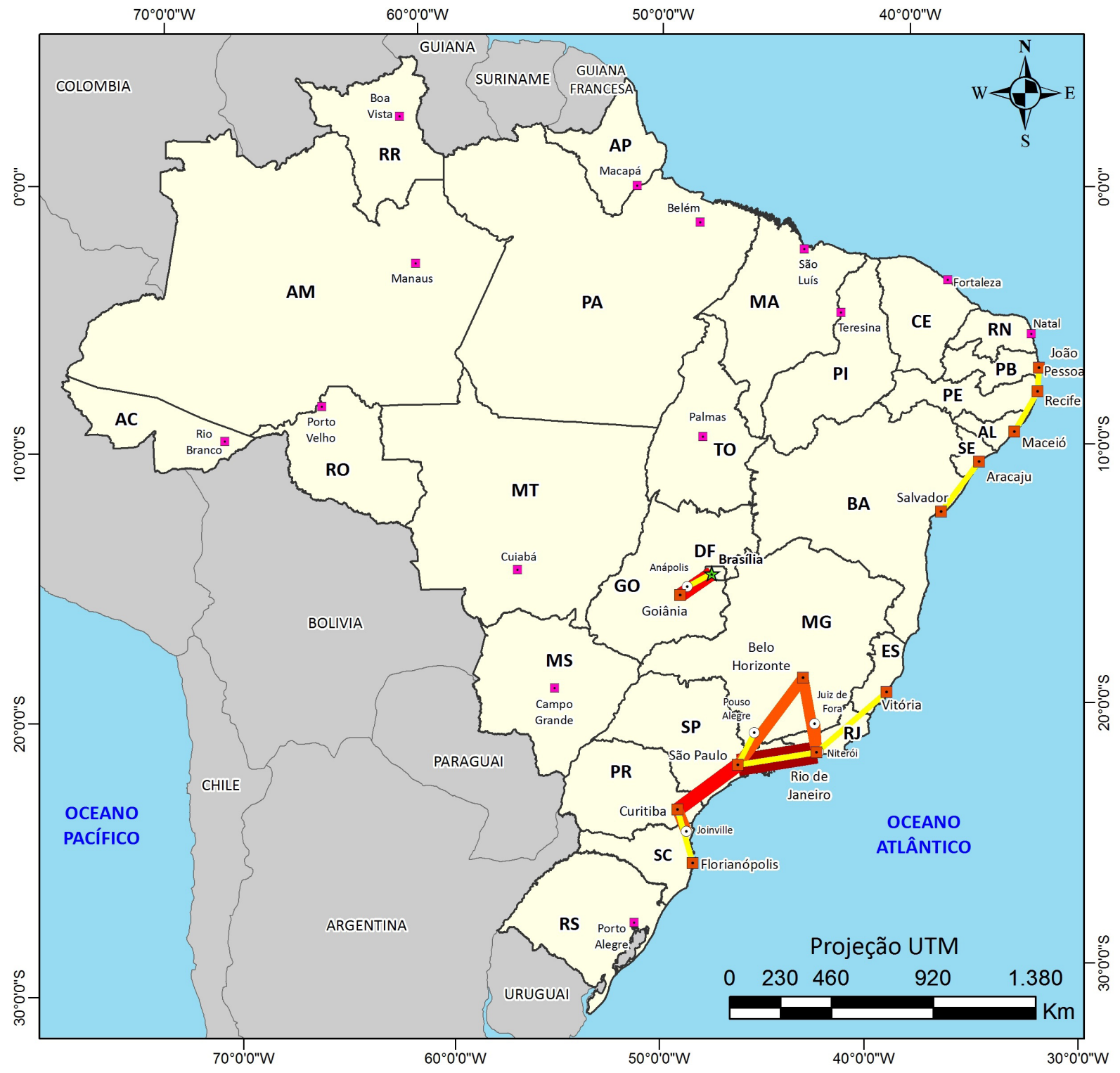

Legenda

\section{Número de passageiros Centralidades}

$$
\begin{aligned}
& -1.099 .756-1.465 .391 \\
& -2.016 .386-2.862 .016 \\
& 2.054 .375-3.324 .715 \\
& \square .654 .531
\end{aligned}
$$

it Capital de país

- Capitais de origem e destino

- Capitais de estado

- Centralidades de origem e destino

Figura 6. BRASIL: Número de passageiros por Unidade da Federação nos serviços rodoviário e semiurbano no período 2010-2015. Fonte: Anuário Estatístico do Transportes Terrestres (AETT) período 2010-2016. Base cartográfica: Departamento Nacional de Infraestrutura de Transportes (DNIT); Instituto Brasileiro de Geografia e Estatística (IBGE). Organização e elaboração: Santos, B. C., 2018.

São Paulo, Rio de Janeiro, Belo Horizonte, Curitiba, Goiânia e Brasília se destacam com os fluxos mais densos no território brasileiro. Conforme a figura 6 ilustra, há a formação de um "triângulo" que conglomera São Paulo - Belo Horizonte - Rio de 
Janeiro, com extensões tentaculares para Vitória e Curitiba derivando dessa forma triangular. $\mathrm{O}$ fato dos trechos mais densos partirem dessas cidades reforçam a primazia desses centros na rede urbana brasileira e na divisão territorial do trabalho no âmbito nacional, já que ambas concentram um grande número de atividades comerciais e de serviços, que atraem importantes contingentes populacionais e dinamiza uma circulação permanente de passageiros. O mesmo ocorre, porém com intensidade menor, entre Brasília e Goiânia e no litoral nordestino, com a cidade de Recife se configurando com um importante nó da rede de transporte rodoviário de passageiros na região e no Brasil - as conexões rodoviárias mais densas a partir de Recife possuem baixas distâncias, o que elucida a central importância do serviço prestado pelos ônibus.

\section{Considerações finais}

o transporte rodoviário interestadual de passageiros no Brasil acompanhou a evolução do território brasileiro desde o início do século XX, evoluindo conforme os paradigmas da produção de bens e serviços pelo país. A necessidade de circular demandou a criação de linhas de ônibus por todo o Brasil, com percursos, distâncias e horários variados para atender às demandas existentes e recorrentes. De um país com população predominantemente rural a um território com maioria populacional urbana, o transporte rodoviário de passageiros levou milhões de pessoas para pontos diversos no Brasil, sendo peça central em um cenário de intensos fluxos migratórios ocorridos na segunda metade do século passado.

Essa atividade econômica engendrou um conjunto expressivo de fluxos de passageiros pelo Brasil e exerceu importante função social ao oferecer opções de deslocamentos para a população que não tinha a possibilidade de se deslocar com veículos particulares ou via transporte aéreo, que, embora tenha adquirido relevância maior nos últimos 15 anos, é altamente seletivo territorialmente em seus atendimentos e nas tarifas cobradas dos passageiros - a necessidade de infraestrutura prévia de alto custo de implantação faz com um conjunto expressivo de cidades brasileiras não tenha aeroportos para receber aeronaves comerciais de médio e grande porte, e aquelas que tem tais estruturas possuem poucas opções de deslocamentos a preços impraticáveis para grande parte de suas populações.

Ou seja, o transporte rodoviário, por conta sobretudo de sua flexibilidade em prestar embarques e desembarques em qualquer ponto do território sem qualquer estrutura prévia, preenche as lacunas deixadas pelo serviço de transporte aéreo. Por esses e outros motivos que linhas com mais de 2 mil quilômetros de extensão, que atendem a dezenas de cidades ao longo do percurso e duram mais de 40 horas ainda existem, pois para parte considerável da população, mesmo com tarifas pouco acessíveis sobretudo para as camadas da população com renda mais baixa, ainda são a única opção de transporte coletivo. Vale ressaltar nos últimos anos o avanço de gratuidades, como o Passe Livre Interestadual para pessoas portadoras de deficiência física, a tarifa com desconto integral para idosos, entre outras políticas públicas que foram discutidas substancialmente durante os governos progressistas no Brasil entre 2003 e 2016 e que propiciaram maior acesso à população para o uso do transporte rodoviário interestadual de passageiros.

O mesmo não pode ser dito de grande parte das unidades da federação no Brasil - poucos estados licitaram seus sistemas de transporte rodoviário intermunicipal e ainda avançam de forma lenta na elaboração de políticas que garantam gratuidades ou descontos aos cidadãos. Trata-se de um setor econômico altamente rentável para 
as companhias privadas que nele atua, o que em certa medida impede a ocorrência de maiores avanços para a população. Em suma, mesmo com o avanço recente do transporte aéreo de passageiros, o rodoviário é muito interessante financeiramente para seus operadores - as empresas de transporte de passageiros.

Agradecimentos: Agradecimentos à agência de fomento Coordenação de Aperfeiçoamento de Pessoal de Nível Superior (CAPES) que financia nossa pesquisa de mestrado iniciada em 2016. 


\section{Q Bibliografia}

» Almeida, J. I. H. (2000). Nordeste do Brasil e o monopólio rodoviário de passageiros. Revista Formação 1 (3), 145-156.

»Antas JR., R. M (2003). A norma e a técnica como elementos constitutivos do espaço geográfico: considerações sobre o ressurgimento do pluralismo jurídico. In: SOUZA, Maria Adélia. Território Brasileiro: usos e abusos. Campinas: Edições Territorial, pp. 77-92.

» Antas JR., R. M. (2005). Território e Regulação - espaço geográfico, fonte material e não-formal do direito. São Paulo: Humanitas.

»Arroyo, M. (200o). A regulação do território no contexto da globalização: uma trama entre as formas globais, nacionais e locais. In: Á. J. de Souza, E. B. Clemente, M. J., Lourenço. Paisagem, território e região: em busca da identidade. Cascavel, PR: Edunioeste/AGB-Bauru, 115-124.

" Arroyo, M. (2006). Dinâmica territorial, circulação e cidades médias. In: E. S. Sposito, M. E. B. Sposito, O. Sobarzo Cidades médias: produção do espaço urbano e regional. São Paulo: Expressão Popular, 71-85.

"Brasil. (2001). Lei federal número 10.233. Disponível em: <http://www.planalto. gov.br/ccivil_03/LEIS/LEIS_2001/L10233.htm>. Acesso em: 09.nov.2013.

» Brasil. (2015). Resolução número 4.770, de 25 de junho de 2015. Disponível em: <http://www.antt.gov.br/passageiros/Resolucao-ANTT-n-4.770-2015.html>. Acesso em: 01.nov.2015.

"Brasil. (2017). Ministério dos Transportes, Portos e Aviação Civil. Empresa de Planejamento e Logística. Anuário Estatístico dos Transportes. Brasília.

"Contel, F. B. (2012). Os sistemas de movimento do território brasileiro. In: M. Santos, M. L. Silveira, O Brasil: território e sociedade no início do século XXI. Rio de Janeiro: Record.

"Corrêa, R. L. (2006a). Estudos sobre a rede urbana. Rio de Janeiro: Bertrand Brasil.

"Corrêa, R. L. (2006b). Interações espaciais. In: I. E. de Castro, P. C. da C. Gomes; R. L. Corrêa. Explorações Geográficas. Rio de Janeiro: Bertrand Brasil, 279-318.

"Corrêa, R. L. (1997). Trajetórias Geográficas. Rio de Janeiro: Bertrand Brasil.

" Dias, L. C. (2012). Redes: emergência e organização. In: I. E. de CASTRO; P. C. da C. Gomes, R. L. Corrêa. Geografia: conceitos e temas. Rio de Janeiro: Bertrand Brasil, 141-162.

»Druciaki, V. P. (2009). As (des) articulações de Guarapuava com Londrina e Maringá: uma análise a partir da rede de transporte rodoviário de passageiros. Dissertação de mestrado. Universidade Estadual de Maringá, Centro de Ciências Humanas, Letras e Artes.

" FABUS. Associação Nacional dos Fabricantes de Ônibus (2015). Mapas modelos período 2003-2014. Disponível em: <http://www.fabus.com.br/producao.htm>. Acesso em: 06.nov.2015.

"Faria, J. E. (1999). O Direito na economia globalizada. São Paulo: Malheiros.

" Fresca, T. M. (2010). Rede urbana e divisão territorial do trabalho. Geografia (Londrina) 19 (2), 115-128. 
» Hirst, P. e Thompson, G. (1998). Globalização em questão. Petrópolis: Editora Vozes.

" Huertas, D. M. (2007). Da fachada atlântica ao âmago da hiléia - integração nacional e fluidez territorial no processo de expansão da fronteira agrícola. $332 \mathrm{f}$. Dissertação de mestrado. Universidade de São Paulo, Faculdade de Filosofia, Letras e Ciências Humanas.

» IBGE. Instituto Brasileiro de Geografia e Estatística (2017). Ligações rodoviárias e hidroviárias. Rio de Janeiro: IBGE.

"Komatsu, A. (2015). Grupo JCA quer ser a "Multiplus" dos ônibus. Jornal Valor Econômico. Disponível em: <http://www.valor.com.br/empresas/2577512/ grupo-jcaquer-ser-multiplus-dos-onibus\#ixzzzghQguplb>. Acesso em: 06.nov.2015.

»Latour, B. (1994). Jamais fomos modernos. São Paulo: Editora 34.

»Lima, N. (2012). Sonhos sobre rodas: a saga dos pioneiros do transporte rodoviário de passageiros no Brasil. Brasília: ABRATI.

»Monbeig, P. (1984). Pioneiros e fazendeiros de São Paulo. São Paulo: Hucitec.

»Oliveira Neto, T. e Nogueira, R. J. B. (2017). Transporte rodoviário de passageiros no Brasil. Revista Transporte y Territorio (17), 229-250.

»Pereira, V. B. (2014). Transportes: história, crises e caminhos. Rio de Janeiro: Civilização Brasileira.

»Raffestin, C. (1993). Por uma geografia do poder. São Paulo: Ática.

"Santos, B. C. dos. (2015). As articulações entre Londrina e São Paulo: uma análise a partir do transporte coletivo rodoviário interestadual de passageiros. $171 \mathrm{f}$. Monografia (Trabalho de graduação individual) - Universidade de São Paulo, Faculdade de Filosofia, Letras e Ciências Humanas.

» Santos, B. C. dos. (2018). Divisão territorial do trabalho e transporte rodoviário interestadual de passageiros: o município de Londrina/PR como um nó para essa circulação. GeoTextos 14 (1), 155-178.

» Santos, M. (2012). A natureza do espaço. Técnica e tempo. Razão e emoção. São Paulo: Edusp.

"Santos, M. (1980). A urbanização desigual: a especificidade do fenômeno urbano em países subdesenvolvidos. Petrópolis: Vozes, 1980.

»Santos, M. (1997). Da política dos Estados à política das empresas. Cadernos da Escola do Legislativo da Assembleia de Minas Gerais 3 (6), 9-23.

»Santos, M. (2014). Metamorfoses do Espaço Habitado. São Paulo: Edusp.

"Santos, M. (2013). Técnica, espaço, tempo: globalização e meio técnico-científicoinformacional. São Paulo: Edusp.

"Santos, M. e Silveira, M. L. (2012). O Brasil: território e sociedade no início do século XXI. Rio de Janeiro: Record.

"Sassen, S. (2010). Sociologia da globalização. Porto Alegre: Artmed.

»Vallaux, C. (1914). El suelo y el Estado. Madrid: Daniel Jorro.

"Wolkowitsch, M. (1973). Géographie des transports. Paris: Librairie Armand Colin.

"Xavier, M. (2012). Os sistemas de engenharia e a tecnicização do território. O exemplo da rede rodoviária brasileira. In: SANTOS, Milton e SILVEIRA, 
María Laura (2012). O Brasil: território e sociedade no início do século XXI. Rio de Janeiro: Record.

\section{Bruno Candido dos Santos / bruno.santos@usp.br}

Bacharel e licenciado em Geografia (2015) pela Universidade de São Paulo. Foi bolsista de Iniciação Científica (PIBIC-CNPq) em 2012-2013 e 2013-2014. Mestrando em Geografia pelo Programa de Pós-Graduação em Geografia Humana da Universidade de São Paulo, com bolsa da Coordenação de Aperfeiçoamento de Pessoal de Nível Superior (CAPES), do governo federal brasileiro. 